Debreceni Jogi Múhely 2017. (XIV.) 1-2.

Debreceni Egyetem, Állam- és Jogtudományi Kar, Debrecen

(University of Debrecen, Faculty of Law, Debrecen)

DOI 10.24169/DJM/2017/1-2/3

\title{
Hámori Antal
}

egyetemi docens, Budapesti Gazdasági Egyetem

\section{A felszolgálási díj szabályozásáról az alapvető jogok biztosának eljárása kapcsán}

Debreceni Jogi Múhely, 2017. évi (XIV. évfolyam) 1-2. szám (2017. június 30.)

DOI 10.24169/DJM/2017/1-2/3

„Előszó” - a téma aktualitása, jelentősége

A felszolgálási dij állami szabályozása ma Magyarországon - fogyasztóvédelmi, munkavállalói, üzemeltetői szempontból is - nagyon aktuális, jelentôs, komplex téma, különös tekintettel a jelenlegi regulációt is sértô, a tanulmányban említésre kerülő gyakorlatokra és a kötelező bevezetés kezdeményezésére, amely a média érdeklődését is felkeltette.*

* Ld. például: a 2017. május 24-i Magyar Nemzet 1. és 5. oldalán megjelent, „Kihez kerülhet a kötelező éttermi szervízdíj?”, „Kihez kerülne a kötelező borravaló? Csak akkor van értelme a szervízdíjnak, ha tényleg a dolgozók kapják, és nem a tulajdonosok teszik zsebre” című cikk; a 2017. május 22-i Magyar Nemzet 6. oldalán szereplő „Megszűnhet a borravaló a szervízdíj miatt. A kötelező, 8-15 százalékos pluszköltség ötlete nem tetszik az étterembe járóknak” című írás szerint „,a Magyar Szállodák és Éttermek Szövetsége (MSZÉSZ) kezdeményezi a magyarországi vendéglátó üzletekben a kötelező szervízdíj bevezetését, mértékére 8-15 százalékot javasolnak” /ld. még például Népszava 2017. május 17.: „Kötelező lesz a borravaló”; Turizmus Online 2017. május 18.: „Kötelező szervízdíjat javasol a szállodaszövetség”; vö. a 2017. május 23-i Magyar Nemzet 9. oldalán olvasható „A kormány szívügye” című írás: „[...] a kötelező szervízdíjat kezdeményező Magyar Szállodák és Éttermek Szövetségére egyre nagyobb nyomás nehezedik a frissen felállt Magyar Turisztikai Ügynökség felől. [...]”; Magyar Nemzet 2017. június 7.: „Közmunkásokkal csökkentenék a munkaerőhiányt a Balatonnál”: „A vendéglátó üzletekben a kötelező szervizdíj bevezetésének ötletét a KISOSZ információi szerint a kisvállalkozók többsége elutasítja, az ötletről nem volt semmiféle szakmai egyeztetés.”; Népszava 2017. június 7.: „Nagy a munkaerőhiány a Balatonnál”: „A vendéglátó üzletekben a kötelező szervízdíj bevezetésének ötletét a KISOSZ információi szerint a kisvállalkozók többsége elutasítja, Kertész Rezső megjegyezte, hogy a felvetésről nem volt semmiféle szakmai egyeztetés.”; Index 2017. május 22.: „A balatoni vendéglátósok nem szeretnének kötelező szervízdíjat”, és Turizmus Online 2017. május 22.: „A balatoni vendéglátósok ellenzik a kötelező szervízdíjat”: „,a Vendéglátó és Turisztikai Szakszervezet ügyvezető elnöke elmondta: a szakszervezet már el is küldte a javaslatot támogató levelét a Magyar Turisztikai Ügynökségnek. A Népszava viszont balatoni vendéglátósokat szólaltatott meg, akik ellenzik a javaslatot. [...]”; Népszava 2017. május 22.: „Nem díjazzák a kötelező borravaló ötletét”: „A balatoni vendéglátói kör egyértelműen elveti a »kötelező borravaló« ötletét.” „»A kisvállalkozói kör csípőből elvet minden kötelező előírást « - mondta [...] a Kisosz Somogy megyei társelnöke.”; Magyar Nemzet 2017. május 27-28. 7. oldal: „Alig burkolt áremelés a szervízdíj?”; Magyar Nemzet 2017. május 25.: „A kormány még nem alakított ki álláspontot, de Lázár személyes véleménye szerint nem lenne jó a vendéglátásban a kötelező szervízdíj bevezetése, mert ez dráguláshoz vezetne. A miniszter szerint az éttermi szolgáltatás áfacsökkentése kellene, hogy finanszírozza a pincérek béremelését.” (vö. kormany.hu 2017. május 18.: „A következő évek tétje Magyarország függetlenségének megőrzése”: „A szállodaszövetség által javasolt kötelező borravalót firtató felvetésre azt felelte [Lázár János]: a kezdeményezést a turisztikai ügynökség mérlegeli, de szerinte nem biztos, hogy a kötelező szervizdíj, amelynek nincs hagyománya Magyarországon, minden vendéglátósnak jó lenne.”; kormany.hu 2017. június 1.: „1,7 millió embert sikerült bevonni a kormányzásba”: „A kötelező szervizdíj tervéről a Miniszterelnökség vezetője ismét azt mondta, hogy nem ért egyet az ötlettel, mert szerinte az egyszerű áremelés lenne. Hozzátette, az éttermi áfacsökkentés fedezet lehet az étterem-tulajdonosoknak a pincérek bérének emelésére.”); továbbá: Turizmus Panoráma 2017. június, 6-9. o.: „Vihart vető javaslatok. Kötelező szervizdíj és garantált béremelés”: „A MÉSZ - amelyik 15 évvel ezelőtt szószólója volt a felszolgálói díj bevezetésének és feltételei kialakításának - nem ért egyet annak kötelezővé tételével, mert az a kisvállalkozások és a vidéki vendéglátás helyzetét rendíti meg, ugyanis a piac nem fogad el ilyen mértékű áremelést.” (9. o.); Turizmus Online 2017. május 10.: „Öt százalékos szállásáfát és kötelező szervízdíjat kér az MSZÉSZ alelnöke”: „a Magyar Szállodák és Éttermek 
Debreceni Jogi Múhely 2017. (XIV.) 1-2.

Debreceni Egyetem, Állam- és Jogtudományi Kar, Debrecen

(University of Debrecen, Faculty of Law, Debrecen)

DOI 10.24169/DJM/2017/1-2/3

A vendéglátó üzletek üzemeltetői a mai szabályozás szerint maguk döntik el, hogy alkalmaznak-e vagy nem felszolgálási dijat; vagyis azon üzemeltetők, akik fel akarják számítani azt, e reguláció szerint megtehetik (akár minden, szabályozás szerinti üzemeltető), saját maguk által mérlegelve a különböző körülményeiket (például a fogyasztókra, vendégekre, a munkavállalókra, a versenytársakra, a jövedelmezőségre gyakorolt hatásokat). Az állam által - a kötelezővé tétellel - ebbe beleszólni (túl a jelenlegi reguláció véleményem szerinti elfogadhatatlanságán) a józan ész, a jogállamiság további megcsúfolása lenne, illogikus volna, a „piacot”, a „versenyt” is rombolná, torzítaná, szükségtelenül és aránytalanul korlátozná, a belső piaci szolgáltatásokról szóló, 2006. december 12-i 2006/123/EK európai parlamenti és tanácsi irányelv (a továbbiakban: Irányelv), amely az Európai Unió Hivatalos Lapjának 2006. december 27-i (L 376.) számában jelent meg, rendelkezéseibe is ütközne /ld. pl. Irányelv 15. cikk (2) bekezdés g) pont: „A tagállamok megvizsgálják, hogy jogrendszerük a szolgáltatási tevékenység nyújtására való jogosultságot vagy a szolgáltatási tevékenység gyakorlását az alábbi megkülönböztetésmentes követelmények bármelyikének való megfeleléshez köti-e: [...] g) rögzített legalacsonyabb és/vagy legmagasabb díjtételek, amelyeknek a szolgáltatóknak meg kell felelnie"/.

A 2005 májusi, „a felszolgálói díj bevezetésével összefüggő jogszabályok módosításáról” szóló, Kormány részére készített gazdasági és közlekedési miniszteri, igazságügyi miniszteri előterjesztés(-tervezet), amelynek - abszurd módon és tartalommal - „A” és „B” változata volt, tartalmazta, hogy a kötelezó

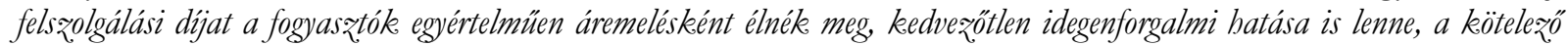
dij beavatkozás a piaci folyamatokba is; szó szerint idézve: „Az »A« változat, a szolgáltatás színvonalától, az éttermi áraktól, a piaci körülményektől és lehetőségektől függetlenül is felszolgálói díjat kell fizetni, amelyet a fogyasztók egyértelműen áremelésként élnek meg. Kedvezőtlen idegenforgalmi hatása is van, mert azoknak az üzleteknek, amelyek éves program alapján előre értékesítik szolgáltatásaikat, azokat éppen az idegenforgalmi szezon kezdetén módosítaniuk kell, mely hatással lehet későbbi üzleti kapcsolataikra is. A kötelező díj, beavatkozás a piaci folyamatokba is. Mindezekről az Ágazati Párbeszéd Bizottság egyes tagjaival, a szakmai képviseletekkel is egyeztetést folytattunk, akik éppen az előzőekben leírtak miatt nem támogatnák a felszolgálói díj kötelező bevezetését. A »B« változat a felszolgálói díjat nem tenné kötelezővé, csak megteremtené a lehetőséget arra, hogy az európai gyakorlathoz hasonlóan az üzemeltető felszolgálási díjat állapíthasson meg maximum $10 \%$ mértékben. $\mathrm{A} » \mathrm{~B}$ « változat nem avatkozik be a piaci folyamatokba, az üzemeltető maga dönti el, hogy felszámol-e ilyen dijat vagy sem.” (Előterjesztés 2-3. oldal) - végül is 2005-ben a „B” változat került elfogadásra, akkor 15\%-os felső határral, amely határ 2009. október 19-től hatálytalan. Emlékezetem szerint 2005-ben az akkori ellenzék a „felszolgálási díj” intézményének bevezetése ellen felszólalt; a diszkriminációs problémákkal kapcsolatos ellenzéki kifogásokra az akkori miniszterelnök (Gyurcsány Ferenc) válaszként azt mondta, hogy majd más területeken is bevezetik ezen (jelentős kedvezményeket, mentességet tartalmazó) szabályozást, amely - a rossz növelése - hál' Istennek nem következett be, viszont most a Magyar Szállodák és Éttermek Szövetsége (MSZÉSZ) egy másik rosszal, a kötelezőséggel kopogtat az „ablakon”, illetve a Magyar Turisztikai Ügynökség ajtaján, asztalán, s hogy - a „szakmai” kapcsolódás („találkozás”) „okán” - a „hozzá nem értés”-t, a „kedvezést” (önös-önző érdeket) mennyiben fedi át (el) az újdonsült („új seprűs”) „bizonyítási vágy”, ma még talán talány, a jogalkotóknak, s jogalkalmazóknak - nehogy csapdába essenek - mihamarább megfejtendő feladvány.

A felszolgálási díj kötelező bevezetését szorgalmazó, fentiekben hivatkozott ez évi kezdeményezés(ek), amennyiben a felszolgálási díj kötelező bevezetésétől várják az említett problémák megoldását, - a felszolgálási díj kötelező bevezetése melletti érvekként, indokolásként - olyan problémákról szólnak, amelyek annyiban egész egyszerủen a mai reguláció alapján orvosolhatók: az üzemeltetők a jelenlegi szabályozás szerint felszámítják a felszolgálási díjat. Ezzel az állam által nem borzoltatják tovább a fogyasztók és mások idegeit, hanem az üzemeltetôk maguk viselik döntéseik következményeit, azaz a

Szövetségének (MSZÉSZ) alelnöke egy szakmai konferencián az egységes, öt százalékos áfakulcs és a kötelező szervízdíj bevezetését kérte a kormányzattól. [...] javasolják kötelező szervízdíj bevezetését januártól minden vendéglátóipari egységre, ennek mértéke 8-15 százalék között lenne.”; Turizmus.com 2017. május 10.: „A turizmus a gazdaság húzóágazata lett”; Turizmus Online 2017. május 11.: „Ez történt a Turizmus és Profit 2017 konferencián”; Népszava 2017. május 11.: „Áfacsökkentésre vár a szállodaipar”; Turizmus.com 2017. május 18.: „Kötelező szervízdíj?” - vö. Turizmus.com 2017. március 23.: „Nyereségesen, mégis fehéren”/. 
Debreceni Jogi Múhely 2017. (XIV.) 1-2.

Debreceni Egyetem, Állam- és Jogtudományi Kar, Debrecen

(University of Debrecen, Faculty of Law, Debrecen)

DOI 10.24169/DJM/2017/1-2/3

politikusok nem „ugornak fejest a semmibe”, nem „mozdulnak árnyékra” (alaptalan, fölösleges politikai csatározásoknak és kudarcoknak is kitéve magukat): azon üzemeltetők, akik alkalmazni akarják - a szerintük „üdvöt” hozó - felszolgálási díjat, felszámítják azt, akik pedig másban látják a reménysugarat, nem követik azt; elvégre a „rendszerváltás” utáni harmadik évtizedben például a MSZÉSZ is rábízhatná a döntést az érintett üzemeltetőkre, s valóban ne akarja megmondani - a jogalkotó útján - az egyik „vállalkozás” a másiknak, hogy milyen üzlet-, munkadíjazás-, „felszolgálási díj”-politikát folytasson. Az egyértelmúen jogellenes, ha a munkáltató (üzemeltetô) nem fizeti ki a munkavállalóknak a „külön jogszabályokban meghatározott adókkal és járulékokkal csökkentett" felszolgálási díjat.

A felszolgálási dij intézményét - az alábbiakban foglaltak szerint - dogmatikai, alkotmányos, fogyasztóvédelmi szempontból is elfogadhatatlannak tartom, az állam által történó kötelezơvé tételét pedig a reguláció abszurditásának nagyon nagy mértékü növelése körébe sorolnám.

\section{A) Az alapvető jogok biztosának eljárása}

A felszolgálási díj jelenlegi magyar állami szabályozásának és a borravaló adómentességének megsemmisítése érdekében történő Alkotmánybírósághoz való fordulást - tizennyolcoldalas alkotmánybírósági indítványtervezettel - kérve 2016. április 18-án (2016. április 15-én kelt) beadvány érkeztetett az alapvető jogok biztosához. ${ }^{1}$

Az Alapvetô Jogok Biztosának Hivatala fóosztályvezetőjének a - 2016. május 23-i keltezésú, AJB3480/2016 ügyszámú iratában adott - tájékoztatása szerint az ügyben megkeresték a nemzetgazdasági minisztert, hogy adjon tájékoztatást a panasszal kapcsolatban, amelynek eredményéről hamarosan értesíteni fogják a panaszost. Az alapvető jogok biztosa 2017. január 17-én kelt, AJB-872/2017 ügyszámú

${ }^{1}$ Ld. Magyarország Alaptörvénye (2011. április 25.) 24. cikk (2) bekezdés e) pont: „(2) Az Alkotmánybíróság [...] e) a Kormány, az országgyúlési képviselők egynegyede, a Kúria elnöke, a legfőbb ügyész vagy az alapvető jogok biztosa kezdeményezésére felülvizsgálja a jogszabályoknak az Alaptörvénnyel való összhangját;" uo. (3) bekezdés a) pont: „(3) Az Alkotmánybíróság a) a (2) bekezdés b), c) és e) pontjában foglalt hatáskörében megsemmisíti az Alaptörvénnyel ellentétes jogszabályt vagy jogszabályi rendelkezést;”; az Alkotmánybíróságról szóló 2011. évi CLI. törvény 24. S (1) bekezdés: „(1) Az Alkotmánybíróság az Alaptörvény 24. cikk (2) bekezdés e) pontja alapján felülvizsgálja a jogszabályoknak az Alaptörvénnyel való összhangját.”; uo. 41. S (1) bekezdés: „(1) Ha az Alkotmánybíróság a 24. \ vagy a 25-26. \szerinti eljárásában a hatályos jogszabály vagy jogszabályi rendelkezés alaptörvény-ellenességét megállapítja, a jogszabályt vagy jogszabályi rendelkezést teljesen vagy részben megsemmisíti.” (a beadvány részét képező alkotmánybírósági indítványtervezetben mind megjelölve és idézve); ld. még az alapvető jogok biztosáról szóló 2011. évi CXI. törvény (a továbbiakban: Ajbt.) 2. \(3) bekezdés: „(3) Az alapvető jogok biztosa kezdeményezheti az Alkotmánybíróságnál a jogszabályok Alaptörvénnyel való összhangjának felülvizsgálatát, az Alaptörvény értelmezését, valamint a kihirdetéstől számított harminc napon belül az Alaptörvény és az Alaptörvény módosítása megalkotására és kihirdetésére vonatkozó, az Alaptörvényben foglalt eljárási követelmények megtartásának vizsgálatát.”; uo. 34. §: „Az alapvető jogok biztosa az Alkotmánybíróságról szóló törvényben meghatározottak szerint az Alkotmánybírósághoz fordulhat.” A beadvány részét képező alkotmánybírósági indítványtervezetben felülvizsgálni és megsemmisíteni kért rendelkezések a következők: a) a felszolgálási díj mértékének megállapításáról, valamint a felszolgálási díj alkalmazásának és felhasználásának szabályairól szóló 71/2005. (IX. 27.) GKM rendelet (a továbbiakban: R.) rendelkezései; b) a termékek eladási ára és egységára, továbbá a szolgáltatások díja feltüntetésének részletes szabályairól szóló 4/2009. (I. 30.) NFGM-SZMM együttes rendelet (a továbbiakban: R2.) 6. \(2) bekezdés „felszolgálási,” szövegrésze; c) a személyi jövedelemadóról szóló 1995. évi CXVII. törvény (a továbbiakban: Szja tv.) 81. S (5) bekezdése, 1. számú melléklet 4.21. alpontja; d) a helyi adókról szóló 1990. évi C. törvény (a továbbiakban: Htv.) 40/C. \(3) bekezdés b) pontja, 55. \22. pont a) alpont vonatkozó szövegrésze; e) a társadalombiztosítás ellátásaira és a magánnyugdíjra jogosultakról, valamint e szolgáltatások fedezetéről szóló 1997. évi LXXX. törvény (a továbbiakban: Tbj.) 4. \ k) pont 1. alpontja, 24. \ (1) bekezdés a) pontja, 26. \(7) bekezdése; f) a társadalombiztosítási nyugellátásról szóló 1997. évi LXXXI. törvény (a továbbiakban: Tny.) 22. \(1) bekezdés e) pontja; g) a társadalombiztosítási nyugellátásról szóló 1997. évi LXXXI. törvény végrehajtásáról szóló 168/1997. (X. 6.) Korm. rendelet (a továbbiakban: Korm. r.) 14. \(5) bekezdése; h) az adózás rendjérôl szóló 2003. évi XCII. törvény (a továbbiakban: Art.) 31. 』 (2) bekezdés 28. pontja; i) az önkormányzati adóhatóság hatáskörébe tartozó adók és adók módjára behajtandó köztartozások nyilvántartásának, kezelésének, elszámolásának, valamint az önkormányzati adóhatóság adatszolgáltatási eljárásának szabályairól szóló 37/2015. (XII. 28.) NGM rendelet (a továbbiakban: NGM r.) 8-9. melléklet vonatkozó részei. 
Debreceni Jogi Múhely 2017. (XIV.) 1-2.

Debreceni Egyetem, Állam- és Jogtudományi Kar, Debrecen

(University of Debrecen, Faculty of Law, Debrecen)

DOI 10.24169/DJM/2017/1-2/3

iratában válaszolt a panaszra.

Az alapvetô jogok biztosa annak ellenére, hogy a beadvány részét képező alkotmánybírósági indítványtervezet a következő szövegrészt magában foglalja: „Álláspontunk szerint a felülvizsgálni és megsemmisíteni kért rendelkezések az Alaptörvény B) cikkének (1) bekezdésével, M) cikkének (2) bekezdésével, XV. cikkének (2) bekezdésével és 18. cikkének (3) bekezdésével ellentétesek, megsértik a fogyasztók megfelelő tájékoztatáshoz való jogát, a jogállamiság (jogbiztonság), a megkülönböztetési tilalom (a jogegyenlőség, a diszkrimináció-mentesség, az egyenló bánásmód), valamint a »jogforrási hierarchia« tiszteletben tartásának alkotmányos követelményét.", ${ }^{2}$ háromoldalas válaszában mindössze az Alaptörvény XV. cikkének (2) bekezdése szempontjából vizsgálódott. ${ }^{3}$

Az alapvető jogok biztosa a következőket írta: „Tisztelt Uram! Köszönöm, hogy megtisztelt a bizalmával és a felszolgálási dijira, valamint a borravaló adómentességére vonatkozó jogszabályi rendelkezésekkel kapcsolatos értelmezési problémájával hozzám fordult. Álláspontja szerint a felszolgálási díj jelenleg hatályos szabályozása és a borravaló adómentessége sérti az Alaptörvény XV. cikkének (2) bekezdése által megfogalmazott megkülönböztetés tilalmát, ezért alaptörvény-ellenes. Beadványában arra kér, hogy forduljak az Alkotmánybírósághoz és kezdeményezzem a kifogásolt szabályozás Alaptörvénnyel való összhangjának vizsgálatát.”; a Nemzetgazdasági Minisztérium válaszában adott tájékoztatás ismertetése után - a 3. oldalon - kifejtve: „A vendéglátás területén adott borravaló adózási szempontból történő megkülönböztetése és a felszolgálási díjra vonatkozó külön szabályozás 2005. október 1-jétől része az adójogi szabályoknak. A jogalkotói cél a juttatások megkillönböztetésekor rész̨en a vonatkozó európai gyakorlat átvétele volt, rész̧en pedig a turisztikeai, vendéglátást ösztönzón gazdaságpolitikai céloknak való megfelelés. Az egyenlö bánásmód követelményének a kérdése pedig ebben a vonatkozásban álláspontom szerint azért nem merüllbet fel, mert arról az alkotmánybírósági gyakorlat tükrében csak akkor beszélhetünk, ha a különbségtétel indokolatlan és egyben az emberi méltóság sérelmével is jár. Ezen második, konjunktív feltétel - azaz az emberi méltóság sérelme - hiányában hátrányos megkülönböztetés nem állapítható meg. A borravalót megalapozó munkakör (azaz a vendéglátás vagy más szolgáltatási szektor) szerinti különbségtétel pedig objektív alapú megkülönböztetést valósít meg, amely nem kapcsolódik az emberi méltóság alapjogához. Mindezekre tekintettel a kifogásolt jogszabályi rendelkezés Alaptörvénnyel való összhangjának megállapítását az Alkotmánybíróságról szóló 2011. évi CLI. törvény 24. \$-a alapján nem kezdeményezem.”

A Nemzetgazdasági Minisztérium válaszában adott tájékoztatás ismertetéséről szóló - az 1-3. oldalon szereplő - rész, a felvezető szöveget ${ }^{4}$ követően, az alábbiakat tartalmazza:

„A jelenlegi szabályok szerint a borravaló adózása alapvetően kettéágazik: a vendéglátásra vonatkozó speciális szabályok mellett az összes többi esetre az adózási szabályok külön nem térnek ki. Ennek megfelelően a hatályos adójogszabályok szerint a borravaló adózása nem egységes, eltérô szabályozás érvényesül a vendéglátáson belül és a vendéglátás területén kívül (pl. töltőállomáson, fodrásznál stb.) adott

\footnotetext{
2 Az Alaptörvény ezen rendelkezései: „B) cikk (1) Magyarország független, demokratikus jogállam.” „M) cikk (2) Magyarország biztosítja a tisztességes gazdasági verseny feltételeit. Magyarország fellép az erőfölénnyel való visszaéléssel szemben, és védi a fogyasztók jogait.” „XV. cikk (2) Magyarország az alapvető jogokat mindenkinek bármely megkülönböztetés, nevezetesen faj, szín, nem, fogyatékosság, nyelv, vallás, politikai vagy más vélemény, nemzeti vagy társadalmi származás, vagyoni, születési vagy egyéb helyzet szerinti különbségtétel nélkül biztosítja." „18. cikk (3) A Kormány tagja törvényben vagy kormányrendeletben kapott felhatalmazás alapján, feladatkörében eljárva, önállóan vagy más miniszter egyetértésével rendeletet alkot, amely törvénnyel, kormányrendelettel és a Magyar Nemzeti Bank elnökének rendeletével nem lehet ellentétes.”

${ }^{3}$ Vö. Ajbt. 37. §: „Ha az alapvető jogok biztosa álláspontja szerint a visszásság valamely jogszabály vagy közjogi szervezetszabályozó eszköz felesleges, nem egyértelmú vagy nem megfelelő rendelkezésére, illetve az adott kérdés jogi szabályozásának hiányára vagy hiányosságára vezethető vissza, a visszásság jövőbeni elkerülése érdekében javasolhatja a jogalkotásra vagy a közjogi szervezetszabályozó eszköz kiadására jogosult szervnél jogszabály vagy közjogi szervezetszabályozó eszköz módosítását, hatályon kívül helyezését vagy kiadását, illetve a jogszabály előkészítőjénél jogszabály előkészítését. A megkeresett szerv állásfoglalásáról, illetve esetleges intézkedéséről hatvan napon belül értesíti az alapvető jogok biztosát.”

4 „A beadványában kifejtett érvekkel összefüggésben a következőkről szeretném tájékoztatni. A panasszal érintett problémakör alapos áttekintése érdekében megkerestem a Nemzetgazdasági Minisztériumot. A Nemzetgazdasági Minisztérium válaszában az alábbiakról tájékoztatott.”
} 
Debreceni Jogi Múhely 2017. (XIV.) 1-2.

Debreceni Egyetem, Állam- és Jogtudományi Kar, Debrecen

(University of Debrecen, Faculty of Law, Debrecen)

DOI 10.24169/DJM/2017/1-2/3

borravalóra. A borravalót gyakran összetévesztik az ún. felszolgálási díjjal, azonban a két fogalom nem ugyanaz. A borravalóval a szolgáltatással való megelégedettséget szokás kifejezni, míg a felszámításra kerülő felszolgálási díjat (szervízdíjat) a számla tartalmazza (hazánkban általában 10\%-os mértékben). A felszolgálási díjat a munkáltatónak tovább kell adnia a munkavállalók részére, ugyanakkor a felszolgálási díj felszámítása nem zárja ki a borravaló adhatóságát. Fontos megjegyezni, hogy a borravaló összege nem szerepel sem a nyugtán, sem a számlán, ezzel ellentétben a felszolgálási díjat a számlán, nyugtán elkülönítetten kell szerepeltetni.

\section{A borravaló}

A borravaló olyan jutalmul kapott összeg, amit a vásárló, fogyasztó önkéntes elhatározásából, szokásjogi alapon abban az esetben ad, amikor elégedett egy szolgáltatással. Két alapvető típusa különböztethetó meg, egyrészt közvetlenül a fogyasztótól kapott borravaló, másrészt a munkáltató által visszaosztott borravaló összege.

A munka törvénykönyvéről szóló 2012. évi I. törvény (a továbbiakban: Mt.) 52. \ (2) bekezdése szerint a munkavállaló a munkáltató előzetes hozzájárulása nélkül harmadik személytől díjazást a munkaviszonyban végzett tevékenységére tekintettel nem fogadhat el, vagy nem köthet ki. Ilyen meghatározott díjazásnak minősül minden olyan vagyoni értékú szolgáltatás, amelyet harmadik személy a munkáltatót megillető szolgáltatáson felül a munkavállalónak nyújt.

A munkavállaló tehát akkor fogadhat el borravalót, ha azt a munkáltató elózetesen engedélyezte. Az engedélyezésre formakényszert az Mt. nem határoz meg, így arra akár szóban, akár a munkáltatónál már kialakult gyakorlat alapján is sor kerülhet, nem szükséges azt írásba foglalni. Lényeges kitétel ugyanakkor, hogy a munkavállaló bére nem csökkenthetô olyan indoklással, hogy egyéb juttatásban is részesül.

\section{A vendéglátáson kívüli területeken közvetlenül a fogyasztótól kapott borravaló}

A személyi jövedelemadóról szóló 1995. évi CXII. törvény (a továbbiakban: Szja törvény) 1. számú melléklet 7.2 pontja szerint egyes tevékenységekhez kapcsolódóan adómentes a magánszemély részére más magánszemély(ek) által ingyenesen vagy kedvezményesen juttatott (fizetett) vagyoni érték; nem alkalmažható e rendelkezés, ha a juttatás (a fizetés) a magánszemély vagy más által teljesített termékértékesítésre (vagyoni érték átengedésére), szolgáltatásnyújtásra tekintettel vagy azzal összefüggésben történik (igy különösen nem adómentes a magánszemély által, hálapénz címén megszerzett vagyoni érték).

A fenti elốrásra tekintettel a vendéglátáson kívüli területeken közvetlenül a fogyasztótól kapott borravaló az Szja törvény szerint adóköteles jövedelem, tekintettel arra, hogy ugyan adómentes a magánszemély részére más magánszemélytôl kapott vagyoni érték, de ez a szabály nem alkalmazható többek között akkor, ha a juttatás szolgáltatásnyújtásra tekintettel vagy azzal összefüggésben történik. A borravalót jellemzően a kapott szolgáltatással való elégedettség kifejezéseként, ellenszolgáltatás jelleggel szokás adni, így a borravalóra nem alkalmazható az adómentes szabály.

Ebből következően a vendéglátáson kívüli területeken közvetlenül a munkavállalónak nyújtott borravaló a magánszemély adóköteles jövedelme, amely után 15\% személyi jövedelemadó és $27 \%$ egészségügyi hozzájárulás fizetési kötelezettség keletkezik. Ebben az esetben a megállapított jövedelem 78\%-át kell jövedelemként figyelembe venni. Ha egyéni vállalkozó kap borravalót, akkor azt az egyéni vállalkozói bevételként kell bevallania és figyelembe vennie.

\section{A vendéglátás területén kapott borravaló}

\subsection{A vendéglátás területén közvetlenül a fogyasztótól kapott borravaló}

Az Szja törvény 1. számú melléklet 4.21 pontja alapján egyes tevékenységekhez kapcsolódóan adómentes a vendéglátó üzlet felszolgálójaként a fogyasztótól közvetlenül kapott borravaló. A vendéglátó üzlet felszolgálójaként a fogyasztótól közvetlenül kapott borravaló tehát olyan adómentes jövedelem, amelyet a magánszemélynek 
Debreceni Jogi Múhely 2017. (XIV.) 1-2.

Debreceni Egyetem, Állam- és Jogtudományi Kar, Debrecen

(University of Debrecen, Faculty of Law, Debrecen)

DOI 10.24169/DJM/2017/1-2/3

akkor sem kell bevallania, ha egyébként más jövedelme is van.

A társadalombiztositás ellátásaira és a magánnyugdijira jogosultakról, valamint e szolgáltatások fedezetéről szóló 1997. évi LXXX. törvény (a továbbiakban: Tbj.) 4. \$ k) pont 1. alpontja szerint járulékalapot képező jövedelem a felszolgálási díj, a vendéglátó ǚlet felszolgálójaként a fogyasztótól közvetlenül kapott borravaló. Ugyanakkor a Tbj. 24. \$(1) bekezdés a) pontja alapján a foglalkoztatott nem fizet nyugdíjjárulékot, valamint egészségbiztosítási- és munkaerőpiaci járulékot a borravaló után.

A Tbj. 26. \(7) bekezdése alapján a vendéglátó üzlet felszolgálója a fogyasztótól közvetlenül kapott borravaló után 15\% nyugdíjárulékot fizethet. A vendéglátó üzlet felszolgálója a borravaló után fizethető járulékot a személyi jövedelemadóról benyújtott bevallásában vallja be, a bevallás benyújtására elöírt határidőig fizeti meg, továbbá a bevallásában adatot szolgáltat a 15\% nyugdíjjárulék alapjáról és összegéről.

\subsection{A munkáltató által visszaosztott borravaló}

A munkáltató által visszaosztott borravaló esete jellemzően akkor merül fel, ha a szolgáltatást igénybe vevő magánszemély bankkártyával teljesíti a vételárat, és a vásárló a tényleges vételártól magasabb összeget fizet elégedettsége kifejezéseként. Megvalósulhat természetesen úgy is, ha a felszolgálók által készpénzben kapott borravaló a szolgáltató (munkáltató) kasszájába kerül. Mindkettő esetben a borravaló a cég bevételének minősül. Az így befolyt borravalót a munkáltató a munkavállalók között valamilyen szempont alapján újra feloszthatja, ez a kiegészítés azonban már a munkavállaló jogviszonyának megfelelően (jellemzően munkabérként) adó- és járulékköteles jövedelem.

\section{A felszolgálási dij}

A szervízdíj, felszolgálási díj a szolgáltatás keretében eladott termékek (ételek, italok) ellenértékén túl a kiszolgálásért külön felszámított tétel az alábbiak szerint.

A felszolgálási díj mértékének megállapításáról, valamint a felszolgálási díj alkalmazásának és felhasználásának szabályairól szóló 71/2005. (IX. 27.) GKM rendelet meghatározása szerint felszolgálási díj a kereskedelemről szóló 2005. évi CLXIV. törvény (a továbbiakban: a kereskedelemrôl szóló törvény) 2. \-ának 30. pontja szerinti vendéglátás keretében a vendégek felszolgáló közremúködésével történő kiszolgálásáért felszámított külön díj. A kereskedelemrôl szóló törvény szerint vendéglátás a kész- vagy helyben készített ételek, italok jellemzően helyben fogyasztás céljából történő forgalmazása, ideértve az azzal összefüggő szórakoztató és egyéb szolgáltató tevékenységet is.

A felszolgálási díj mértéke jelenleg nincsen jogszabályban meghatározva, jellemzően a vendéglátóegység vezetője határozza meg annak mértékét és összegét. A felszolgálási díjat a fogyasztó részére adott számlán, nyugtán elkülönítetten kell feltüntetni. A felszámított felszolgálási díjat havonta kell a vendéglátásban közvetlenül - az üzletben - közremúködőknek kifizetni. A kifizetésnek meg kell egyeznie a felszolgálási díj befolyt összegének adókkal és járulékokkal csökkentett hányadával.

A felszolgálási díj közremúködők közötti felosztásának szabályairól, arányáról az üzemeltetőnek - ha a munkahelyen munkavállalói érdek-képviseleti szervezet múködik - az érdekképviseleti szervezettel kell írásban megállapodnia. Ha a munkahelyen munkavállalói érdek-képviseleti szervezet nem múködik, a felszolgálási díj felosztásának arányáról az üzemeltetőnek a közremúködôkkel kell írásban megállapodni.

Az Szja törvény 1. számú melléklet 4.21. pontja alapján egyes tevékenységekhez kapcsolódóan adómentes a magánszemély által külön jogszabály szerint felszolgálási díj címen megszerzett bevétel. Vagyis a magánszemélynek (felszolgálónak) nem keletkezik személyi jövedelemadó fizetési kötelezettsége a felszolgálási díj után.

A Tbj. 4. \ k) pont 1. alpontja szerint járulékalapot képező jövedelem a felszolgálási díj, a vendéglátó üzlet felszolgálójaként a fogyasztótól közvetlenül kapott borravaló. Ugyanakkor a Tbj. 24. \(1) bekezdés a) pontja alapján a foglalkoztatott nem fizet nyugdíjjárulékot, valamint egészségbiztosítási- és munkaerôpiaci járulékot a felszolgálási díj után. 
Debreceni Jogi Múhely 2017. (XIV.) 1-2.

Debreceni Egyetem, Állam- és Jogtudományi Kar, Debrecen

(University of Debrecen, Faculty of Law, Debrecen)

DOI 10.24169/DJM/2017/1-2/3

A Tbj. 26. \(7) bekezdése alapján a felszolgálási díj után a foglalkoztató - a foglalkoztatott helyett - 15\% nyugdíjárulékot fizet, míg a foglalkoztatott nem fizet nyugdíjjárulékot, valamint egészségbiztositási- és munkaerőpiaci járulékot.”

B) Az alapvető jogok biztosa válaszának reflexiója, a szabályozás kritikája

Az alapvetó jogok biztosa tehát az Alaptörvény B) cikkének (1) bekezdése, M) cikkének (2) bekezdése és 18. cikkének (3) bekezdése, a jogállamiság (jogbiztonság), a fogyasztók megfelelö tájékoztatáshoz való joga és a ,jogforrási bierarchia" tisz̨teletben tartásának alkotmányos követelménye szempontjából - a beadványban foglaltak ellenére - nem vizsgálódott, amely véleményem szerint elfogadhatatlan.

Különösen érdekes ezek után az alapvető jogok biztosa válaszának utolsó mondatát olvasni: „Öszintén remélem azonban, hogy tájékoztatásom segítségére szolgál, és a jövőben is állok rendelkezésére minden olyan ügyben, amelynek vizsgálatára az alapvető jogok biztosáról szóló 2011. évi CXI. törvény feljogosít.”

Ahhoz, hogy a tisztelt Olvasó eldönthesse, az alapvető jogok biztosának tájékoztatása, benne a Nemzetgazdasági Minisztérium tájékoztatása mennyire tudott segítségül („nóvummal”) szolgálni a panaszosnak, állion itt a beadvány részét képező alkotmánybírósági indítványtervezet Indokolásának B) része („A₹ indítványozói állaspont kifejtése”), ${ }^{5}$ vagyis a fentieket követően érdemesnek tartom újfent megnézni közelebbról, hogy - a panaszos szerint - milyen problémák vetődtek fel a szóban forgó regulációval kapcsolatban. ${ }^{6}$

\section{Bevezetés}

Magyarországon a felszolgálási díj alkalmazása 2005. október 1-tôl megengedett,7 azelőtt tilos volt. ${ }^{8} A$

\footnotetext{
${ }^{5} \mathrm{Az}$ alapvető jogok biztosa válaszának minden mondatát a fentiekben szó szerint idéztem; a beadvány részét képező alkotmánybírósági indítványtervezet 1-2. oldalát, kérelmet magában foglaló részét és Indokolásának A) részét (ld. 12. lábjegyzet) az előzőekben ugyancsak ismertettem.

${ }^{6}$ Legutóbb ld. Hámori Antal: A felszolgálási dij és a fogyasztók védelme. Közjogi Szemle 2016. 3. sz. 49-58.

${ }^{7} \mathrm{Az}$ akkori szabályozás részletes ismertetéséhez, elemzéséhez ld. Hámori Antal: Felszolgálási dij a magyar jogban. In: Budapesti Gazdasági Fő́iskola Tudományos Évkönyve 2006, Stratégiák 2007 és 2013 között. Szerk. Majoros Pál. Budapest, Budapesti Gazdasági Főiskola, 2007. (440) 304-316. [,A »felszolgálási dij» bevezetésének lényegét képezi, hogy e díj után a foglalkoztatottnak nyugdíjárulék- és egészségbiztosítási járulékfizetési kötelezettsége nem keletkezik, a foglalkoztatónak pedig csak 15\%-os nyugdíjbiztosítási járulékot kell fizetnie, amely magában foglalja a nyugdíjjárulékot is; a felszolgálási díj után magán-nyugdijpénztári tagdijat nem kell fizetni. A »felszolgálási dijß elemzéséhez (kritikájához) látni kell: a felszolgálási díj áfát nem tartalmazó összegét a vendéglátó üzletet üzemeltetô vállalkozásnak az értékesítés nettó árbevételeként (tehát árbevételként) kell elszámolnia a fogyasztásról kiállított számla, nyugta alapján; a felszolgálási dijból befolyt összegnek a külön jogszabályokban meghatározott adókkal és járulékokkal csökkentett értékét pedig személyi jellegú egyéb kifizetésként (azaz költségként) kell könyvelnie havonta.” „86/2005. Számviteli kérdés - Hogyan történik a 2005 októberétől bevezetett éttermi felszolgálási díj számviteli elszámolása? (Számvitel, Adó, Könyvvizsgálat 2005/11. sz.), APEH tájékoztató a felszolgálási díj és a borravaló utáni járulékfizetési kötelezettségrőll (Adó és Ellenőrzési Értesítő 2005/11. sz.), APEH tájékoztató a 2005. évi személyi jövedelemadó bevallásával és elszámolásával kapcsolatos kifizetői és munkáltatói feladatokról és az adatszolgáltatásról (uo. 2005/13. sz.; helyesbítette: uo. 2006/1-2. és 3. sz.-ban megjelent APEH közlemény), PMAPEH együttes tájékoztató a felszolgálási díjjal és a borravalóval kapcsolatos általános forgalmi adó és járulék fizetési kötelezettségekről (uo. 2005/14. sz.), PM-APEH együttes tájékoztató a felszolgálási díjjal kapcsolatos általános forgalmi adó és járulékfizetési-kötelezettség megállapításáról [a 2005. évi 14. számban megjelent tájékoztatás kiegészítése] (uo. 2006/3. sz.), APEH közlemény az adóigazgatási azonositásta alkalmas nyugta adását biztosító pénztárgépek és taxaméterek forgalmazásának, használatának feltételeiről és az azzal összefüggő nyilvántartási, elszámolási és adatszolgáltatási kötelezettségekról (uo. 2006/1-2. sz.), APEH közlemény a felszolgálási díj alkalmazásának, kezelésének szabályairól a vendéglátóhelyeken üzemelỏ pénztárgépek esetében (uo. 2006/4. sz.)." 304., 313.] A reguláció 2006-ban az Alkotmánybíróság előtt indítvánnyal megtámadtatott (1001/B/2006. számú ügy), de az Alaptörvény és az Abtv. rendelkezései folytán az eljárás megszűnt: ld. XX/1081-1/2012. AB végzés (2012. január 16.); vö. Alaptörvény 24. cikk (2) bekezdés e) pont, Abtv. 71. \$ (1) bekezdés.

${ }^{8}$ Ld. Hámori Antal: A vendéglátás fogyasztóvédelmi jogi szabályozása. Budapest, Label Kft., 2003. (328) 18-21. /„A
} 
Debreceni Jogi Múhely 2017. (XIV.) 1-2.

Debreceni Egyetem, Állam- és Jogtudományi Kar, Debrecen

(University of Debrecen, Faculty of Law, Debrecen)

DOI 10.24169/DJM/2017/1-2/3

felszolgálási díj mértékének megállapitásáról, valamint a felszolgálási dij alkalmazásának és felhasználásának szabályairól szóló 71/2005. (IX. 27.) GKM rendelet (R.), amely három \$-ból áll, kétszer módosult. Az első alkalommal 2008. december 28-i hatálybalépéssel9 - az 1. \(3) bekezdése, ${ }^{10}$ amely a második módosítással -2009.

felszolgálásért (kiszolgálásért), illetve a »teríték«-ért (couvert) ellenérték kérése (felszámítása) akkor is jogellenes, ha azt előre, írásban (pl. az étlapon, itallapon, illetve árlapon) közölték a vendéggel (fogyasztóval); és akkor is, ha az nem százalékban, hanem a Magyar Köztársaság törvényes fizetőeszközében (a Magyar Köztársaság területén törvényes fizetőeszköz szerint) van meghatározva, egyértelműen, könnyen azonosíthatóan és tisztán olvashatóan feltüntetve. A fogyasztóvédelemről szóló törvény »A fogyasztók tájékoztatása« címet viselő IV. fejezetében, az ár feltüntetése szabályainak körében kimondja: »(1) Az áru fogyasztói forgalombahozatalakor a forgalmazó köteles - külön jogszabályban meghatározottak szerint - a fogyasztót írásban tájékoztatni az eladási árról és az egységárról, illetve a szolgáltatás díjáról. (2) Az eladási árat, az egységárat és a szolgáltatás diját a Magyar Köztársaság területén törvényes fizetőeszköz szerint meghatározva, egyértelműen, könnyen azonosíthatóan és tisztán olvashatóan kell feltüntetni. (3) A Magyar Köztársaság területén fogyasztói forgalomba hozott áru és szolgáltatás áraként a fogyasztói forgalomban fizetendő árat kell feltüntetni. (4) Több eladási ár vagy szolgáltatási díj egyidejű feltüntetése esetén az áru eladási árán, vagy a szolgáltatás díján a feltüntetett legalacsonyabb eladási árat vagy szolgáltatási dijat kell érteni.«. Az üzletek múködéséről és a belkereskedelmi tevékenység folytatásának feltételeiről szóló kormányrendelet kimondja, hogy az áru árát forintban (tehát nem százalékban) fel kell tüntetni. A vendéglátó üzletek kategóriába sorolásáról, valamint ártájékoztatásáról szóló miniszteri rendelet szerint az ártájékoztató (étlap, itallap, árlap, ártábla, egyedi árkiírás) jól olvashatóan a termék neve mellett a Magyar Köztársaság törvényes fizetőeszközében meghatározva tartalmazza az egyes ételek, készítmények, termékek - jellegétől függően - mennyiségére vagy mértékegységére megállapított, a fogyasztói forgalomban fizetendő árát. A felszolgálásért (kiszolgálásért) ellenérték kérése - a Magyar Köztársaság területén törvényes fizetőeszköz szerint meghatározva, egyértelműen, könnyen azonosíthatóan és tisztán olvashatóan feltüntetve is - azért jogellenes, mert a vonatkozó pénzügyi jogi rendelkezéseket sérti; mind az általános forgalmi adó-fizetési kötelezettséget, mind pedig a munka díjazásával kapcsolatos járulékfizetési kötelezettséget sérti. Ahogy azt a fentiekben idézett APEH iránymutatás megfogalmazza: »... a vendéglátóhelyen a szolgáltatásért kifizetett ellenérték nem csak az elfogyasztott étel, ital árát foglalja magába, hanem minden olyan járulékos szolgáltatás ellenértékét, amely ahhoz kapcsolódik (az étel elkészítése, felszolgálása stb.).«; a vendéglátásban nem termékértékesítés történik, hanem egy komplex sqolgáltatás, és ez vonatkozik minden vendéglátó üzletre; a felszolgálás (kiszolgálás) mint munkának a pénzben kifejezett ellenértékét (díjazását) az árképzés során az árrésen belül a költségek, a bérköltségek között kell megjeleníteni, és mind a foglalkoztatottnak (munkavállalónak), mind pedig a foglalkoztatónak (munkáltatónak) viselnie kell a bérjárulékokat. [...]”-18-19. (hivatkozásokkal)/. Ld. még Gazdasági és közlekedési miniszter, igazságügyi miniszter: Előterjesztés a Kormány részére a felszolgálói díj bevezetésével összefüggő jogszabályok módosításáról. 2005. május (a továbbiakban: Tervezet). Előterjesztés (Budapest, 2005. május 3.) 2.: „A hatályos magyar szabályozás jelenleg nem ad lehetőséget arra, hogy a vendéglátó üzletben az étlapon, az itallapon, illetve árlapon a termék neve mellett feltüntetett fogyasztói áron kívül más címen is fizettessenek a vendéggel. Ennek ellenére - éppen az említett nemzetközi gyakorlatra figyelemmel - hazánkban is előfordul, hogy a felszolgálásért ún. szervízdíjat (felszolgálási díjat) is felszámítanak, amely gyakorlatot - jogellenessége miatt - eddig a fogyasztóvédelmi hatóságok bírságoltak."; egyes pénzügyi tárgyú törvények módosításáról szóló 2005. évi LXXXII. törvény indokolása (a továbbiakban: Indokolás), „Az 1. §-hoz”: „Az európai gyakorlatnak megfelelően a vendéglátó üzleteknek lehetőségük lesz arra, hogy a »borravalót « legálisan feltüntessék árlapjaikon és az a vendég által fizetett számlában elkülönült tételként megjelenítsék.”, és „A 10-11. \-hoz”: „Ezért indokolt az árak megállapításáról szóló 1990. évi LXXXVII. törvény módosításával ennek legális hazai alkalmazását is lehetővé tenni.”. Meglátásunk szerint egy szűk, de annál befolyásosabb gazdasági (vendéglátóipari tulajdonosi) érdekcsoport érvényesítette sajátos, nem fogyasztóbarát, diszkriminatív szempontjait (ld. az alábbiakban), „legalizálva” ezzel az addigi egyértelmúen jogellenes és szankcionált gyakorlatot, így szüntetve meg a bírságolásokat. Az állam így feladta annak vizsgálatát, hogy az üzemeltetők egy része - a bírságolások ellenére - valójában miért is alkalmaz „felszolgálási dijat” (vö. pl. munkabér közterhei, munkabér, illetve munkabéremelés egy részének „kiváltása” - ld. az alábbiakban).

${ }^{9}$ Ld. egyes miniszteri rendeleteknek a fogyasztóvédelmi szabályozás változásával összefüggő módosításáról szóló 27/2008. (XII. 20.) NFGM rendelet (a továbbiakban: 1Mód.) 19. §: „Ez a rendelet kihirdetését követő 8. napon lép hatályba, és az azt követô napon hatályát veszti.”

10 Az R. 1. S (3) bekezdés eredeti szövege: „(3) Az étlapon feltüntetett felszolgálási díj mértéke a vendég által elfogyasztott termékek ét- és itallapon, valamint árlapon feltüntetett, az általános forgalmi adót tartalmazó árának 15\%-át nem haladhatja meg. Az előzőek szerint számított felszolgálási díj az általános forgalmi adót is tartalmazza. A fogyasztó részére adott számlán, nyugtán a fogyasztó által fizetendő összegben a felszolgálási díjat elkülönítetten kell feltüntetni.”; az 1Mód. 17. \-a: „A felszolgálási díj mértékének megállapításáról, valamint a felszolgálási díj alkalmazásának és felhasználásának szabályairól szóló 71/2005. (IX. 27.) GKM rendelet 1. \(3) bekezdésének helyébe a következő rendelkezés lép: »(3) A felszolgálási díj mértéke a vendég számára értékesített termékek az általános forgalmi adót tartalmazó árának 15\%-át nem haladhatja meg. Az előzőek szerint számított felszolgálási díj 
Debreceni Jogi Múhely 2017. (XIV.) 1-2.

Debreceni Egyetem, Állam- és Jogtudományi Kar, Debrecen

(University of Debrecen, Faculty of Law, Debrecen)

DOI 10.24169/DJM/2017/1-2/3

október 19-től - hatálytalan, ${ }^{11}$ az utóbbival - az alábbiak szerint - az 1. \(1)-(2) bekezdése, ${ }^{12}$ és a 2. \13 hatályát vesztette ${ }^{14}$ (a 3. \a 2005. október 1-jei hatálybalépésről rendelkezik). E módosítások mögött többek között - szabályozásbeli változások és pontatlan, illetve helytelen szövegezés miatti korrekciós igények álltak. ${ }^{15}$

az általános forgalmi adót is tartalmazza. A fogyasztó részére adott számlán, nyugtán a fogyasztó által fizetendő összegben a termékek felszolgálási díj nélküli árát és a felszolgálási díjat elkülönítetten kell feltüntetni.«".

11 Ld. a közigazgatási hatósági eljárás és szolgáltatás általános szabályairól szóló 2004. évi CXL. törvény módosításával és a belső piaci szolgáltatásokról szóló 2006/123/EK irányelv átültetésével összefüggően egyes miniszteri rendeletek módosításáról szóló 26/2009. (X. 16.) ÖM rendelet (a továbbiakban: 2Mód.) 19. \ (1) bekezdés, 21. $₫ 2$. pont.

${ }^{12}$ Ld. 2Mód. 4. \$.

${ }_{13}$ Az R. 2. \-a: „E rendelet alkalmazásában a) rendezvény: az üzemeltető által vendéglátó üzletben vagy más helyszínen felszolgáló közremúködésével, előzetes megrendelésre nyújtott zártkörű szolgáltatás, b) közremúködő: az a munkavállaló, aki a vendéglátó üzlet szolgáltatásaiban részt vesz."

${ }^{14}$ Ld. 2Mód. 21. \2. pont.

${ }^{15} \mathrm{Az}$ elsö módositást a pontatlan, helytelen megfogalmazás indokolta; ld. R. 1. \ (3) bekezdés és 1Mód. 17. §; vö. 1Mód. 21. §: „Ez a rendelet a következő uniós jogi aktusoknak való megfelelést szolgálja: a) a Tanács 73/44/EGK irányelve (1973. február 26.) a háromkomponensú textilszálkeverékek mennyiségi elemzésére vonatkozó tagállami jogszabályok közelítéséről - I. melléklet II.9.1. pont [a 15. S]; b) az Európai Parlament és a Tanács 96/73/EK irányelve (1996. december 16.) a kétkomponensủ textilszálkeverékek mennyiségi elemzésének egyes módszereiről - II. melléklet [a 12-14. \$]; c) az Európai Parlament és a Tanács 96/74/EK irányelve (1996. december 16.) a textiltermékek elnevezéséről - 1. cikk, 6. cikk (4) bek., 8. cikk (1) bek., (2) bek. b) és d) pont, 9. cikk (3) bek. d) pont és 10. cikk (1) bek. b) pont [az 1. $\int$, a 2. $\int$, a 4-8. $\int$ és a 10-15. \$]; d) a Bizottság 97/37/EK irányelve (1997. június 19.) a textiltermékek elnevezéséről szóló 96/74/EK európai parlamenti és tanácsi irányelv I. és II. mellékletének a műszaki fejlődéshez történő hozzáigazításáról - 1. cikk 7. pont [a 10. \$]; e) a Bizottság 2008/322/EK határozata (2008. április 18.) a kizárólag gyermekbiztos öngyújtók forgalomba hozatalát biztosító és az újszerú öngyújtók forgalomba hozatalát tiltó, tagállamok által meghozandó intézkedések elóíásáról szóló 2006/502/EK bizottsági határozat érvényességének meghosszabbításáról [a 19. \(4) bekezdés].”. A második módositás mögött jogszabályi változások és pontosítás iránti igények (is) álltak; ld. R. 1. \(1)-(2) bekezdés eredeti szövege: „(1) A vendéglátó üzlet szolgáltatásai után az üzemeltetó felszolgálási díjat számíthat fel. (2) A felszolgálási díjat a vendéglátó üzletek kategóriába sorolásáról, valamint ártájékoztatásáról szóló 43/1998. (VI. 24.) IKIM rendelet (a továbbiakban: R.) 1. \ (5) bekezdésének a) pontjában meghatározott hagyományos üzemeltetésủ rendszerben múködő vendéglátó üzletben, rendezvényen - a külön jogszabályban meghatározott munkahelyi vendéglátás és a vendéglátó üzletben folytatott előfizetéses étkeztetés kivételével - lehet felszámolni. Ha a vendéglátó üzlet több értékesitőhellyel rendelkezik, az R. 1. \-a (5) bekezdésében meghatározott üzemelési rendszereket értékesítőhelyenként külön-külön kell figyelembe venni.”; 2Mód. 4. §: „A felszolgálási dij mértékének megállapításáról, valamint a felszolgálási díj alkalmazásának és felhasználásának szabályairól szóló 71/2005. (IX. 27.) GKM rendelet [a továbbiakban: 71/2005. (IX. 27.) GKM rendelet] 1. \(1) és (2) bekezdéseinek helyébe a következő rendelkezések lépnek: »(1) A felszolgálási díj a kereskedelemrôl szóló 2005. évi CLXIV. törvény 2. \$-ának 30. pontja szerinti vendéglátás keretében a vendégek felszolgáló közremúködésével történő kiszolgálásáért felszámított külön dij. (2) A fogyasztó részére adott számlán, nyugtán a felszolgálási dijat elkülönítetten kell feltüntetni.«”, 23. \: „E rendelet 1-12. \$-ai, 15-18. \$-ai, valamint 22. \$-a a belső piaci szolgáltatásokról szóló, 2006. december 27-i 2006/123/EK európai parlamenti és tanácsi irányelvnek való megfelelést szolgálja.”; vö. R2. 8. \ b) pont: „Hatályát veszti [...] a vendéglátó üzletek kategóriába sorolásáról, valamint ártájékoztatásáról szóló 43/1998. (VI. 24.) IKIM rendelet.” (7. S: „Ez a rendelet a kihirdetését követő 8. napon lép hatályba."); az R2. 8. \ b) pontjának kritikájához ld. Hámori Antal: A vendéglátó üzletek kategóriába sorolásának jogi szabályozása. Magyar Jog 2010. 3. sz. 164-171., vö. Hámori Antal: A szálláshely osztályba, a vendéglátó üzlet kategóriába sorolása bejelentésének jogi természetéről. Magyar Jog 2008. 6. sz. 423-428. Megemlítendő, hogy az R. 1. \-ának jelenleg hatályos (1) bekezdése bizonyos szempontból tágabbnak túnik, mint az R. 1. \-ának eredeti (2) bekezdése, mert a munkahelyi vendéglátás és a vendéglátó üzletben folytatott előfizetéses étkeztetés körében is történhet a kiszolgálás felszolgáló közremúködésével; ugyanakkor kérdés, hogy az R. 1. \ (4) bekezdés első mondata szerinti „üzlet” kizárja-e az üzleten kívüli rendezvényt, és akkor a második módosítás e tekintetben szűkít? A pontosítás („helyesbítés”) szempontjából kérdés, hogy az R.-ben - vö. a pénzügyi jogi szabályozással (ld. az alábbiakban - „magánszemély”, „foglalkoztatott”) -: „A „közremüködö« csak a felszolgáló?” - vö. R. 1. \(4) bekezdés első mondat: „Az (1) bekezdés szerint felszámított felszolgálási dijat havonta kell a vendéglátásban közvetlenül - az üzletben - közremúködőknek kifizetni.”, vagy arról van szó, hogy az R. 1. \-ának jelenleg hatályos (1) bekezdése a ,felszolgálo"-val mindössze a közvetett kiszolgálást fejezi ki, amelyre kiterjed a felszolgálási díj, de az R. 1. \(4) bekezdésének első mondata mutatja meg, hogy kik részesülnek a felszolgálási dijból, akik azonban nemcsak a 
Debreceni Jogi Múhely 2017. (XIV.) 1-2.

Debreceni Egyetem, Állam- és Jogtudományi Kar, Debrecen

(University of Debrecen, Faculty of Law, Debrecen)

DOI 10.24169/DJM/2017/1-2/3

\section{Az R. jelenleg hatályos szabályai - értelmezési kérdések és kritika}

Az R. jelenleg hatályos szabályai szerint a felsz̧olgálási dij a kereskedelemről szóló 2005. évi CLXIV. törvény (a továbbiakban: Kertv.) 2. §-ának 30. pontja szerinti vendéglátás ${ }^{16}$ keretében a vendégek felszolgáló közremúkeödésével történő kissolgálásáért felszámított külön dij,, ${ }^{17}$ amit havonta kell a vendéglátásban këzvetlenül a₹. ü̃letben - közremüködóḱnek kifizetni. ${ }^{18}$ A kifizetésnek meg kell egyeznie a felszolgálási díj befolyt összegének - külön jogszabályokban meghatározott - adókkal és járulékokkal csökkentett hányadával. ${ }^{19} \mathrm{~A}$ felszolgálási díj közremúkeödök közötti felosztásának szabályairól, arányáról az üzemeltetőnek - ha a munkahelyen munkavállalói érdek-képviseleti szervezet múködik - az érdek-képviseleti szervezettel kell írásban megállapodnia. ${ }^{20} \mathrm{Ha}$ a munkahelyen munkavállalói érdek-képviseleti szervezet nem múködik, a felszolgálási dij felosztásának arányáról az üzemeltetőnek a közreműködőkkel kell írásban megállapodni. ${ }^{21}$ Az R. e rendelkezéseken kívül még azt tartalmazza, hogy a fogyasztó részére adott számlán, nyugtán a felszolgálási díjat elkülönítetten kell feltüntetni. ${ }^{22}$

Az R. jelenleg hatályos szabályai alapján véleményünk szerint továbbra is kérdés: az R.-ben a „vendéglátásban közvetlenül - az ü̈letben - köəremüködök" csak felszolgálók, vagy mások is; tehát kikneke, jár a felszolgálási dij?23

Értelmezésünkben az R. 1. \(1) bekezdése szerinti „közremúködés”-től „elválnak” az R. 1. \(4)-(5) bekezdése szerinti közremúködők, mivel a „vendéglátásban közvetlenül - az ü̃letben - közremüködók” tágabb kört fog át, mint a „felszolgáló”. A felszolgálási dijat csak a felszolgáló közremúködésével történő kiszolgálásért szabad felszámítani, de egyrészt a felszolgáló is csak közremúködik (más, a vendéglátásban közvetlenül - az üzletben - közremúködők mellett) a kiszolgálásban, másrészt a felszámított felszolgálási dij havi kifizetése a vendéglátásban közvetlenül - az üzletben - közremúködők körére terjed ki, márpedig a vendéglátásban közvetlenül - az üzletben - nemcsak felszolgálók múködnek közre (ld. pl. üzletvezetô, barman, vendéglátóipari eladó); vagyis az R. 1. S(4)-(5) bekezdése szerinti „közremúködők” nemcsak a felszolgálókra terjed ki.24

Összefoglalóan a feltett kérdés első felére a válasz véleményünk szerint: az R. 1. S-ának jelenleg hatályos (1) bekezdése a ,felszolgálo"-val mindössze a közvetett kiszolgálást fejezi ki, amelyre kiterjed a felszolgálási díj, és az R. 1. \(4) bekezdésének első mondata „mutatja meg”, hogy kik részesülnek a felszolgálási díjból, akik azonban nemcsak a felszolgálók..25

felszolgálók (részletesen ld. az alábbiakban), ld. Hámori (2007) i.m. 311. A belső piaci szolgáltatásokról szóló, 2006. december 12-i 2006/123/EK európai parlamenti és tanácsi irányelv (a továbbiakban: Irányelv), amely az Európai Unió Hivatalos Lapjának 2006. december 27-i (L 376.) számában jelent meg, és 2006. december 28-tól hatályos, véleményünk szerint nem teszi szükségessé a felszolgálási díj 15\%-os felső határának eltörlését, vagyis az R. 1. \ (3) bekezdésének hatályon kívül helyezését (részletesen ld. az alábbiakban). A 2Mód. 23. \-a tartalmazza a 2Mód. 4. \-át, de nem foglalja magában a 2Mód. 21. \2. pontját, amely a 15\%-os felső határt tartalmazó 1. \(3) bekezdést hatályon kívül helyezte.

${ }^{16}$ Ld. Kertv. 2. \30. pont: „E törvény alkalmazásában [...] 30. vendéglátás: kész- vagy helyben készített ételek, italok jellemzően helyben fogyasztás céljából történő forgalmazása, ideértve az azzal összefüggő szórakoztató és egyéb szolgáltató tevékenységet is".

${ }^{17}$ Ld. R. 1. $\int(1)$ bekezdés.

${ }^{18}$ Ld. R. 1. $\int$ (4) bekezdés első mondat.

${ }^{19}$ Ld. R. 1. $\int(4)$ bekezdés második mondat (ld. általános forgalmi adó, nyugdíjjárulék, részletesen az alábbiakban).

${ }^{20}$ Ld. R. 1. S (5) bekezdés első mondat.

${ }^{21}$ Ld. R. 1. S (5) bekezdés második mondat.

${ }^{22}$ Ld. R. 1. S (2) bekezdés.

${ }^{23}$ A Tervezet melléklete csak felszolgálókat említ: „A külön jogszabály rendelkezik arról, hogy a felszolgálási díjat a felszolgálóknak ki kell fizetni.” (11.); az Indokolás viszont már a „vendéglátó üzlet tevékenységében közremúködő magánszemélyek”-ről szól: „A felszolgálási díj mértékéről, feltüntetéséről és felszámításának módjáról külön jogszabályok rendelkeznek, mint ahogy a külön jogszabály mondja ki azt is, hogy a felszolgálási díjat a vendéglátó üzlet tevékenységében közreműködő magánszemélyek között ki kell osztani. [...]” (ld. Indokolás, „Az 1. \-hoz”).

${ }^{24}$ Megjegyezzük, a Tervezet „felszolgálói dîj” megfogalmazással is élt, azonban nem ez vált a szabályozás részévé, s persze ezen elnevezés is csak elnevezés, azaz nem „tartalom”.

25 Ezt alátámasztani látszik az Szja tv. 1. számú mellékletének 4.21. alpontja, mivel az a felszolgálási díj 
Debreceni Jogi Múhely 2017. (XIV.) 1-2.

Debreceni Egyetem, Állam- és Jogtudományi Kar, Debrecen

(University of Debrecen, Faculty of Law, Debrecen)

DOI 10.24169/DJM/2017/1-2/3

Kérdés, hogy a „vendéglátásban közvetlenül - az ǚletben - közremüködók” köre kiterjed-e például az „üzletben” raktáros munkakört betöltő személyekre?

Az, hogy a „vendéglátásban közvetlenül - az üzletben -” az üzemeltetó vendéglátása, vagyis nem Magyarország vendéglátása (vagy „a vendéglátás” - mint olyan) szempontjából értendő, az R. 1. \-ának rendelkezéseiből értelmezésünk szerint egyértelmúen következik, ugyanis azok címzettje az „üzemeltető”. Kérdés, hogy az „üzlet” (a „munkahely”) minden munkavállalója a „vendéglátásban közvetlenül közremúködők” körébe tartozik-e (az értelmezésre csak ráerősít-e a „- az üzletben -” szövegrész); vagyis arról van-e szó, hogy az „üzlet” minden munkavállalója az üzemeltető vendéglátásában közvetlenül közremúködő, ${ }^{26}$ és például a taxis, aki a vendéget az üzlethez fuvarozza, a közvetetten közremúködő, vagy mind a közvetlenül, mind a közvetetten „közremúködők” az „üzleten” belül értelmezendők?

Eme utóbbi értelmezésen belül kérdés, hogy például a szakács, a cukrász - az R. szerint - közvetlenül vagy közvetetten közremúködőnek minősül-e? Amikor a szakács, a cukrász a vendég asztalánál készíti, tálalja az ételt (pl. valamilyen flambírozott különlegességet), akkor egyértelmúen közvetlenül közremúködőnek (a „vendéglátásban közvetlenül - az üzletben - közremúködő”-nek) tűnik, de amikor - mint általában - a konyhában tevékenykedik („,süt, főz”), vajon közvetlenül közremúködik, a „vendéglátásban közvetlenül az üzletben -" közremúködik? A Kertv. vendéglátás definíciója alapján - eme utóbbi értelmezés szerint is - mindkét esetben: a válasz inkább igenlô. ${ }^{27}$ Ezt alátámasztani látszik az is, hogy a Kertv. alkalmazásában „üzlet: kereskedelmi tevékenység folytatása céljából létesített vagy használt épület, illetve önálló rendeltetési egységet képező épületrész, helyiség, ideértve az elsődlegesen raktározás, tárolás célját szolgáló olyan épületet vagy épületrészt is, amelyben kereskedelmi tevékenységet folytatnak”; 28 „árusítótér: az üzleten belül a termék vásárlóknak történő bemutatására és értékesítésére szolgáló terület"; ${ }^{29}$ továbbá a kereskedelmi tevékenységek végzésének feltételeiről szóló 210/2009. (IX. 29.) Korm. rendelet 28. §-ának d) pontja szerint e rendelet alkalmazása szempontjából „melegkonyhás vendéglátóhely: meleg- és hideg ételeket, cukrászati készítményeket, sütő- és édesipari termékeket, kávét, szeszesitalt és szeszmentes italokat forgalmazó üzlet, ahol az ételeket meghatározóan a helyszínen készítik”; vagyis az „üzlet” fogalmába nemcsak az „árusítótér” („,fogyasztótér”, „,vendégtér”) értendő, hanem például a konyha és a raktár is.

Kérdés tehát ezek után, hogy hol a „határ”? Az utóbbi értelmezésen belül: vajon a „mosogató” munkakörben foglalkoztatott munkavállaló, amikor a drinkbár-pultban - akár a barman-nel együtt mosogatja a poharakat (vagy egyébként is), a „vendéglátásban közvetlenül - az üzletben - közremúködő”? $\mathrm{S}$ a „takarító" munkakörben foglalkoztatott munkavállaló, amikor a vendégtérben a nyitvatartási idő alatt például a szőnyegre esett ételt összesöpri (vagy egyébként is), ilyennek minősül?

Az „üzlet” kapcsán az is kérdés, hogy az ún. „házon kívüli rendezvény” esetében, amikor noha van a vendéglátásban közvetlenül közremúködő, nem szabad alkalmazni a felszolgálási díat? Ha az „üzlet” fogalmát szorosan vesszük, akkor nem szabad, de ha kiterjesztően (figyelemmel a felszolgálási díj céljára³0), akkor fel szabad számítani azt.

vonatkozásában a „magánszemély”-t tartalmazza, és a fogyasztótól közvetlenül kapott borravaló tekintetében szerepelteti a „felszolgáló”-t.

${ }^{26}$ Ezt látszik erősíteni az Indokolásnak a „vendéglátó üzlet tevékenységében közreműködő magánszemélyek” idézett szövegrésze (ld. Indokolás, „Az 1. \-hoz”).

27 A „helyben készített ételek” „forgalmazása” inkább magában foglalja ezen ételek elkészítését, mint pusztán feltételezi azt. A vendéglátás ugyanis egy komplex szolgáltatás, amely felöleli a „termelés”-t is, vegyes típusú, illetve vállalkozási szerződésről van szó, nem egyszerūen adás-vételről; kétségtelen, a belkereskedelemről szóló 1978. évi I. törvény 8. \$-a szerinti vendéglátás-definíció ezt jobban tükrözte: „A vendéglátás ételek, italok készítése és eladása fogyasztóknak, felhasználóknak, viszonteladóknak, továbbá a vendéglátással összefüggő szórakoztató és egyéb szolgáltató tevékenység; a munkahelyen a dolgozók, valamint az oktatási és nevelési intézményekben a tanulók és a gyermekek étkeztetése.”; részletesen ld. Hámori (2003) i.m. 14-18.

${ }_{28}^{2}$ Ld. Kertv. 2. \$27. pont.

${ }^{29}$ Ld. Kertv. 2. $\int 1$. pont.

30 Ld. R. 1. \ (1) bekezdés: „[...] vendéglátás keretében a vendégek felszolgáló közreműködésével történő kiszolgálásáért [...].”; az R. 1. (4) bekezdésének első mondatában az „üzlet” ráerősít az üzemeltető vendéglátására. 
Debreceni Jogi Múhely 2017. (XIV.) 1-2.

Debreceni Egyetem, Állam- és Jogtudományi Kar, Debrecen

(University of Debrecen, Faculty of Law, Debrecen)

DOI 10.24169/DJM/2017/1-2/3

Ismereteink szerint az említett értelmęési problémák tarka képet mutatnak a gyakorlatban, amelyek jelentôs tisztázásra, megfeleló hivatásos jogalkalmazói reflexióra szorulnak, és persze a jogalkotó is a dilemma után járhat(ott volna), mert a kifejtettek szerint nagyon is indokoltnak tűnik; hiszen nem mindegy, hogy azok részesülnek-e a felszolgálási díjban, akiknek jár, vagy azok is, akiknek nem jár, sértve az elôbbiek jogát (véleményünk szerint az egyértelmúen jogellenes, ha az üzemeltetô a felszolgálási díj egy részét megtartja magának). Azt gondoljuk, hogy a felvetett értelmezési kérdések a jogbiztonság követelménye szempontjából is relevánsak. ${ }^{31}$

Kétségtelen, „nem árt”, ha a jogalkotó és a jogalkalmazó a józan észnek ${ }^{32}$ megfelelően a természetes valósághoz igazodik, vagyis finoman fogalmazva nem rugalmatlan; tehát, a felszolgálási díj állami megengedéséhez képest, a „vendéglátásban közvetlenül - az ü̈letben - kö:remüködoók” köre nem szúkül le a felszolgálói munkakörre, de ugyanakkor nem is „határtalan”, ${ }^{33}$ és a pénzügyi jogi jogalkotás is ehhez kötődik. Mielőtt azonban áttérnénk bonyolultabb (pénzügyi jogi) területre, szeretnénk rámutatni egyrészt a 15\%-os felső határ eltörlésének - véleményünk szerint - súlyosan aggályos voltára, másrészt pedig magának a felszolgálási dínnak az elfogadhatatlanságára, amely miatt annak idején (2005-ben) emlékezetünk szerint - az akkori ellenzék felszólalt.

A felszolgálási díj abszurditását jól mutatja a 15\%-os felső határ eltörlésének következménye, amely szerint a fogyasztó (vendég) a bruttó díj34 akár dupláját is fizetheti, ami nyilvánvalóan a józan ésszel szembe megy

31 Vö. Alaptörvény B) cikk (1) bekezdés: „Magyarország független, demokratikus jogállam.”; a jogalkotásról szóló 2010. évi CXXX. törvény 2. \(1) bekezdés: „A jogszabálynak a címzettek számára egyértelmúen értelmezhető szabályozási tartalommal kell rendelkeznie.” Véleményünk szerint az R. idézett rendelkezési alapján az egyértelmú, hogy a felszolgálási dijat az R. szerinti közreműködőknek ki kell fizetni, az arány a közremúködők között értendó, vagyis az üzemeltető abból jogszerúen nem tarthat meg magának semmit (a jogsértésekkel szemben pedig megfelelően fel kell lépni); a kérdés az, hogy kik az R. szerinti közremúködők.

${ }^{32}$ Ld. pl. Alaptörvény 28. cikk: „A bíróságok a jogalkalmazás során a jogszabályok szövegét elsősorban azok céljával és az Alaptörvénnyel összhangban értelmezik. Az Alaptörvény és a jogszabályok értelmezésekor azt kell feltételezni, hogy a józan észnek és a közjónak megfelelő, erkölcsös és gazdaságos célt szolgálnak.”

${ }^{33}$ Vö. pl. a borravaló vendég szándéka szerinti rendeltetése (ld. az alábbiakban).

${ }^{34}$ A fogyasztóvédelemről szóló 1997. évi CLV. törvény (a továbbiakban: Fgytv.) 14. \-ának (1)-(7) bekezdése jelenleg a következő szabályokat foglalja magában: ,(1) A fogyasztót - a (2) bekezdésben meghatározott kivétellel - a külön jogszabályban meghatározottak szerint írásban tájékoztatni kell a fogyasztóknak megvételre kínált termék eladási áráról és egységáráról, illetve a szolgáltatás dijáról. (2) Nem kell alkalmazni e $\$ rendelkezéseit az árverés útján értékesítendő termékre, ha annak kikiáltási (induló) árát az árverési tájékoztató meghatározza. (3) Az eladási árat, az egységárat, illetve a szolgáltatás diját egyértelmúen, könnyen azonosithatóan és tisztán olvashatóan kell feltüntetni. (4) Az eladási árat és az egységárat, illetve - határon átnyúló szolgáltatásnyújtás kivételével - a szolgáltatás díját Magyarország törvényes fizetőeszközében kifejezve, a fizetőeszköz nemét (forint) vagy annak rövidítését ( $\mathrm{Ft}$ ) megjelölve kell feltüntetni. (5) A termék eladási áraként és egységáraként, illetve a szolgáltatás dijaként a fogyasztó által ténylegesen fizetendő, az általános forgalmi adót és egyéb kötelező terheket is tartalmazó árat kell feltüntetni. (6) Ha a termékre vonatkozó kereskedelmi kommunikáció megjelöli a termék eladási árát - amennyiben jogszabály eltérően nem rendelkezik -, az egységárat is meg kell adni. (7) Több eladási ár vagy szolgáltatási díj egyidejủ feltüntetése esetén a vállalkozás köteles a feltüntetett legalacsonyabb eladási ár vagy szolgáltatási díj felszámítására." Az Fgytv. alkalmazásában (a jelenleg hatályos 2. \ szerint): „a) fogyasztó: az önálló foglalkozásán és gazdasági tevékenységén kívül eső célok érdekében eljáró természetes személy, aki árut vesz, rendel, kap, használ, igénybe vesz vagy az áruval kapcsolatos kereskedelmi kommunikáció, ajánlat címzettje. A békéltető testületre vonatkozó szabályok alkalmazásában - a fogyasztói jogviták online rendezéséről, valamint a 2006/2004/EK rendelet és a 2009/22/EK irányelv módosításáról szóló, 2013. május 21-i 524/2013/EU európai parlamenti és tanácsi rendelet alkalmazásának kivételével - fogyasztónak minősül a fentieken túlmenően az önálló foglalkozásán és gazdasági tevékenységi körén kívül eső célok érdekében eljáró, külön törvény szerinti civil szervezet, egyházi jogi személy, társasház, lakásszövetkezet, mikro, kis- és középvállalkozás is, amely árut vesz, rendel, kap, használ, igénybe vesz vagy az áruval kapcsolatos kereskedelmi kommunikáció, ajánlat címzettje,” „f) termék: minden birtokba vehető forgalomképes ingó dolog - ide nem értve a pénzt, az értékpapírt és a pénzügyi eszközt - és a dolog módjára hasznosítható természeti erő, g) szolgáltatás: termék, ingatlan vagy vagyoni értékú jog értékesítésén kívül minden olyan - ellenszolgáltatás fejében végzett - tevékenység, amely a megrendelő, illetve megbízó igényének kielégítésére valamely eredmény létrehozását, teljesítmény nyújtását vagy más magatartás tanúsítását foglalja magában,” „ll) áru: a termék, az ingatlan és a vagyoni értékủ jog, valamint a szolgáltatás, m) eladási ár: a termék egy egységére vagy adott mennyiségére vonatkozó ár, n) egységár: a termék e törvény végrehajtására kiadott jogszabályban meghatározott mértékegységére 
Debreceni Jogi Múhely 2017. (XIV.) 1-2.

Debreceni Egyetem, Állam- és Jogtudományi Kar, Debrecen

(University of Debrecen, Faculty of Law, Debrecen)

DOI 10.24169/DJM/2017/1-2/3

(a kétezer forintos rántott szelet négyezerért kelne el). E változáshoz képest mely’ hatóság, bíróság mondja (húzza) meg a mércét, vagy talán az ezerszázalékos felszolgálási díj is normális (jogszerú) jelenség?

Erre persze mondják egyesek, hogy a tájékoztatási követelményeknek megfelelnek, s így az (a „döntés”, a vendég „döntése”) a „szerződési szabadság” része. Ha pedig a tájékoztatási követelményeknek nem felelnek meg, akkor a felszolgálási díj felszámítása jogellenes, és a vendég nem köteles azt megfizetni. Meglátásunk szerint ebből a szempontból is érdemes szemügyre venni a felszolgálási dij felszámításával kapcsolatos tájékoztatási elôírásokat és gyakorlatot.

A termékek eladási ára és egységára, továbbá a szolgáltatások dija feltüntetésének részletes szabályairól szóló 4/2009. (I. 30.) NFGM-SZMM együttes rendelet (R2.) 6. \(2) bekezdése - 2009. szeptember 23-ai hatálybalépéssel35 kimondja: ha a vállalkozás valamely termék forgalmazásával közvetlen összefüggésben nyújtott szolgáltatásáért külön dijat számít fel (így különösen a felszolgálási, szállítási, kiszállási díjat), a külön díjat a termék árának feltüntetésére vonatkozó szabályok szerint, az érintett termék árával együtt (ugyanazon árkiíráson vagy árjegyzéken) kell feltüntetni. ${ }^{36}$

Az R2. 2. \-ának (1) bekezdése alapján a termék eladási árát - a (2) és a (4) bekezdésben meghatározott kivétellel - a) a terméken, annak csomagolásán vagy a termékhez egyéb módon rögzítve, vagy b) a közvetlenül a termék mellett elhelyezett egyedi árkiíráson vagy a fogyasztó számára a megvenni kívánt termék kiválasztásakor könnyen hozzáférhető árjegyzéken (ideértve az étel-, illetve itallapot is) kell feltüntetni. ${ }^{37}$ A $2 . \$(4)$ bekezdése szerint a Kertv.-ben meghatározott vendéglátás keretében értékesített termék vonatkozásában az eladási árat vagy az egységárat kell feltüntetni. ${ }^{38}$

Az R2. 3. §-ának (1) bekezdése értelmében a termék egységárát, ha az nem egyezik meg a termék eladási

vonatkozó ár,” „q) kereskedelmi kommunikáció: a fogyasztókkal szembeni tisztességtelen kereskedelmi gyakorlat tilalmáról szóló törvényben ekként meghatározott fogalom”. A fogyasztókkal szembeni tisztességtelen kereskedelmi gyakorlat tilalmáról szóló 2008. évi XLVII. törvény 2. 『-ának e) pontja alapján e törvény alkalmazásában: „e) kereskedelmi kommunikáció: a vállalkozás önálló foglalkozásával vagy gazdasági tevékenységével közvetlenül összefüggésben történő információközlés, függetlenül annak megjelenési módjától, eszközétől”, a b) pont szerint „vállalkozás: aki a kereskedelmi gyakorlat tekintetében önálló foglalkozásával vagy gazdasági tevékenységével összefüggő célok érdekében jár el”. A Polgári Törvénykönyvről szóló 2003. évi V. törvény 8:1. \ (1) bekezdés 3-4. pontja alapján e törvény alkalmazásában „3. fogyasztó: a szakmája, önálló foglalkozása vagy üzleti tevékenysége körén kívül eljáró természetes személy; 4. vállalkozás: a szakmája, önálló foglalkozása vagy üzleti tevékenysége körében eljáró személy”. A ,fogyasztô’ fogalmához ld. pl. Hámori Antal: A fogyasztók védelme és az új Ptk. Magyar Jog 2015. 5. sz. 257-273.; Hámori Antal: A nem természetes személy laikusok fogyasztói védelmének változásai (A „fogyasztó” fogalom változásai a magyar jogban - különös tekintettel az Fgytv.-re és az új Ptk.-ra). In: Multidiszciplináris kihívások, Sokszínű válaszok 3. Szerk. Hamar Farkas. Budapest, Budapesti Gazdasági Főiskola, 2013. (85) 28-32.; Hámori Antal: A fogyasztó fogalom aktuális jogalkotási és jogalkalmazási dilemmái. Agora 2012. 9. sz. 45-64.; Hámori Antal: A vállalkozások fogyasztói minősége. Gazdaság és Jog 2012. 9. sz. 8-11.; Hámori Antal: Kötelező jótállás fogyasztóvédelem. Gaz̧daság és Jog 2011. 6. sz. 21-24.; Hámori Antal: A „fogyasztó”-fogalom „dilemmái” különös tekintettel az Fgytv. módosításában és az új Ptk.-javaslatban foglaltakra. Magyar Jog 2009. 2. sz. 88-97.

${ }^{35} \mathrm{Ld}$. a termékek eladási ára és egységára, továbbá a szolgáltatások díja feltüntetésének részletes szabályairól szóló 4/2009. (I. 30.) NFGM-SZMM együttes rendelet módosításáról szóló 21/2009. (IX. 15.) NFGM-SZMM együttes rendelet (a továbbiakban: R3.) 6-7. \: „6. \ (1) Ez a rendelet - a (2) bekezdésben meghatározott kivétellel - a kihirdetését követő 8. napon lép hatályba. (2) Az 5. \az e rendelet kihirdetését követő 30. napon lép hatályba. 7. @ Az R. 6. \ (2) bekezdésében az »(ugyanazon árkiíráson, árjegyzéken vagy árlapon)« szövegrész helyébe az »(ugyanazon árkiíráson vagy árjegyzéken)« szöveg lép."

${ }^{36}$ E rendelkezés szempontjából is elmondható, hogy a fogyasztók számára (is) nagyon hátrányos változást hozott az R2. 8. \-ának b) pontja: a vendéglátó üzletek kategóriába sorolásáról, valamint ártájékoztatásáról szóló 43/1998. (VI. 24.) IKIM rendelet hatályon kívül helyezése; ld. (a motivációkhoz is) Hámori: i.m. (9. jegyzet, 2010.). A felszolgálási dijjal kapcsolatos fogyasztóvédelmi hatósági gyakorlathoz ld. például Nemzeti Fogyasztóvédelmi Hatóság: Összefoglaló jelentés. A vendéglátó-ipari vállalkozások, a közterületi, illetve alkalmi értékesítést végző kereskedők, valamint a személyszállító szolgáltatást nyújtók tevékenységének nyári ellenőrzéséről, kiemelt figyelemmel a turisták által kedvelt helyszínekre, Budapest, 2016. szeptember 22. 12 o.: „Azok a felszolgáló közremúködésével üzemelő vendéglátó-ipari egységek, amelyek felszolgálási díjat érvényesítettek a vendéglátás során, a felszolgálási dijjról és annak mértékéről 1-1 esetet kivéve minden esetben tájékoztatták a fogyasztókat.” (5. o.).

${ }^{37}$ Ld. R3. 1. S.

${ }^{38}$ Ld. R3. 2. S. 
Debreceni Jogi Múhely 2017. (XIV.) 1-2.

Debreceni Egyetem, Állam- és Jogtudományi Kar, Debrecen

(University of Debrecen, Faculty of Law, Debrecen)

DOI 10.24169/DJM/2017/1-2/3

árával, a) a terméken, annak csomagolásán vagy a termékhez egyéb módon rögzítve, vagy b) a közvetlenül a termék mellett elhelyezett egyedi árkiirráson vagy a fogyasztó számára a megvenni kívánt termék kiválasztásakor könnyen hozzáférhetô árjegyzéken (ideértve az étel-, illetve itallapot is) kell feltüntetni. ${ }^{39}$

Az R2. 4/A. \-a pedig tartalmazza, hogy az olyan vendéglátó üzlet esetében, ahol a vendéget felszolgáló közremúködésével szolgálják ki, az üzlet étel- és italválasztékához kapcsolódó eladási árakat, illetve egységárakat bemutató árjegyzéket az üzlet bejáratán kívül, annak közelében is el kell helyezni. ${ }^{40}$

Az R2. rendelkezései kapcsán érdemes felhívni a figyelmet arra, hogy - véleményünk szerint - a felszolgálási díj és a szállítási, kisszállási díj között dogmatikai szempontból is jelentős különbség van, mert a felszolgálási dij szerinti kiszolgálás lényegi sajátja (szerves részę) a szolgáltatásnak, az ü̃letben történik, amelyért a vendég díjat fizet (ráadásul a vendéglátás, a vendéglátó szolgáltatás komplex, sajátos szolgáltatás ${ }^{41}$ ), ami a szállitásról és a kiszállásról nem mondható el. ${ }^{42}$

Ami pedig a tájékoztatásbeli különbségeket illeti: a) a 15\%-os felső határ eltörlésével a „mérték” az R.-ben nem jelenik meg, s így (szó szerinti, kifejezett) ellentmondás nincsen például az Fgytv. 14. \-ának (4) bekezdésével, de a „mérték” a gyakorlatban „mértéktelenül” tovább él (az R. ekként hatályosul), ami a szabályozás korrekciójának szükségességét is felveti; ${ }^{33}$ b) a tájékoztatási gyakorlat rendkívül tarka, mondhatni, nagy mértékben nem fogyasztóbarát [\%-os, kis betűs, hiányos, „eldugottt”: sérti az Fgytv. 14. 『-ának (3)-(4) bekezdését], ami hatékony jogalkalmazói fellépést kíván.

\section{Az R. dogmatikai, alkotmányossági problémái - a fogyasztóvédelem megtorpanásai}

\subsection{A felszolgálási díj természete}

A felszolgálási dij - az említettek szerint - a vendéglátásban közvetlenül (az üzletben) közremúködők munkájának díjazására, jövedelemként szolgál; vagyis nem más, mint munka dijazása, voltaképpen egyfajta „teljesítménybérezés” (legalábbis a forgalomhoz igazodik). ${ }^{44} \mathrm{E}$ közremúködők - az ismertetett konjunktív feltételek fennállása esetén - azért részesülnek (a munkabéren túl) felszolgálási dịban, mert „kišolgálnak”. Ez a megoldás ellentmond annak a koncepciónak, hogy „,a vendéglátó helyen a szolgáltatásért kifizetett ellenérték nem csak az elfogyasztott étel, ital árát foglalja magába, hanem minden olyan járulékos szolgáltatás ellenértékét, amely ahhoz kapcsolódik (az étel elkészítése, felszolgálása stb.)". ${ }^{45}$

A szabályozás alapján egyértelmúen lehet látni, hogy a felszolgálási dij nem azonos a borravalóval; noha a Tervezet indokolása szerint: „A tervezett szabályozás a felszolgálási díjat azért legalizálja, hogy ezáltal a borravaló ne zsebből zsebbe vándoroljon, hanem nyomon követhető legyen." 46 Ezt a szándékot tükrözi a következő mondat is: „A vendég által önkéntesen adott borravaló sorsa nem követhető nyomon, a döntő hányada zsebből zsebbe vándorol, ez után személyi jövedelemadót annak ellenére sem fizetnek, hogy erre a hatályos rendelkezések szerint is kötelesek lennének azok, akik kapják.” ${ }^{47}$ A Tervezetben a szövegező -

\footnotetext{
${ }^{39}$ Ld. R3. 3. S.

${ }^{40}$ Ld. R3. 5. S.

${ }^{41}$ Részletesen ld. Hámori (2003) i.m. 14-18.

42 A vendéglátásban, amikor ún. „,házon kívüli rendezvény”-rôl, „kitelepülés”-ről, „kiszállás”-ról, és ennél fogva „szállítás”-ról van szó, a bruttó dij magában foglalja a „kitelepülés”-sel, „kiszállás”-sal, „,szállítás”-sal kapcsolatos költségeket, így a helyben (az üzletben) történő fogyasztáshoz képest fennálló többletmunka díjazásának költségeit is; amikor pedig pusztán étel, ital házhozszállítása történik, és a távolságra tekintettel külön szállítási dijat számíthatnak fel, akkor éppúgy nem üzletben történő fogyasztásról (szolgáltatás-igénybevételről) van szó, mint amikor például a bútort a forgalmazó szállítja el az üzletből a fogyasztó otthonába (a fogyasztó persze a forgalmazó szállítása hiányában sem fogyasztja el a bútort az üzletben, hanem otthon használja el, de forgalmazói szállítás nélkül nem fizet külön szállítási díjat, miként a vendég sem, amikor saját maga hozza el a vendéglátó üzletből az ételt, italt).

${ }^{43}$ Bővebben ld. az alábbiakban.

${ }^{44}$ Ld. a következőkben a pénzügyi jogi szabályozást.

45 Ld. 2000/124. APEH iránymutatás (a számla kötelező adattartalma vendéglátó-ipari szolgáltatás esetén megerősítette az AEÉ 2001/11. sz. Melléklete a szakmai iránymutatások felülvizsgálatáról); Hámori (2003) i.m. 16-17.

${ }^{46} \mathrm{Ld}$. Tervezet. Előterjesztés 2.

${ }^{47}$ Ld. Tervezet. Előterjesztés 2.
} 
Debreceni Jogi Múhely 2017. (XIV.) 1-2.

Debreceni Egyetem, Állam- és Jogtudományi Kar, Debrecen

(University of Debrecen, Faculty of Law, Debrecen)

DOI 10.24169/DJM/2017/1-2/3

érdekes módon - a borravaló legalizálásáról beszél (érdekes, mert a borravaló akkoriban is legális volt), és a felszolgálási díjról, mint a borravaló helyett bevezetésre kerülő intézményről szól: „A tervezet azáltal, hogy legalizálja a borravalót, megteremti a személyi jövedelemadó kötelezettség teljesítésének ellenőrizhetőségét, ugyanakkor számolni kell azzal, hogy a felszolgálási dij emeli a vendéglátás árait azzal, hogy az eddig önkéntes - a szolgáltatás színvonalától is függó és azt elismerő - borravaló helyett a szolgáltatás színvonalától függetlenül kötelező költséggé válik a fogyasztó számára." 48 A borravaló és a felszolgálási díj közti különbséget nem megfelelően megjelenítő álláspontról tanúskodik a következő megfogalmazás is: „A vendéglátásban elfogadott gyakorlat a borravaló, ugyanakkor az Európai Unió számos országában a borravaló helyett felszolgálási díjat alkalmaznak, amelynek adótartalma jobban nyomon követhetô.”49 Az Indokolás szerint: „Az európai gyakorlatnak megfelelően a vendéglátó üzleteknek lehetőségük lesz arra, hogy a »borravalót« legálisan feltüntessék árlapjaikon és azt a vendég által fizetett számlában elkülönült tételként megjelenítsék."50

\subsection{A felszolgálási dij dogmatikai ellentmondásai a polgári jog és a munkajog tükrében}

A felszolgálási díj létjogosultságának kérdése polgári jogi és munkajogi szempontból is megközelíthető: a cselekmény (a felszolgálási díj alkalmazása) az „autonóm mozgástér védelmének elve”, valamint a „jóhiszeműség és tisztesség (jóerkölcs) elve” alapján is megítélhető (ld. még „rendeltetésszerű joggyakorlás elve” és ,joggal való visszaélés tilalmának elve”). A normatív jellegú, ún. operatív alapelvek közvetlenül is alkalmazhatók; „,minden törvényes rendelkezésben bennerejlő (immanens) magnak tekintendôk”. ${ }^{51}$

A vendég (fogyasztó) elismerendő és védendő törvényes érdeke (döntési és cselekvési szabadsága, autonóm személyi és vagyoni mozgástere), hogy saját maga eldönthesse, akarja-e pénzben is kifejezni a felszolgálással (kiszolgálással) kapcsolatos elégedettségét vagy nem, és azt is, hogy ki(k)nek, illetve, ha nem elégedett, akkor ne kelljen külön is fizetnie a felszolgálásért (kiszolgálásért), és ekként is cselekedhessen. ${ }^{52}$

A munka díjazását (a munkabért) a foglalkoztatott (munkavállaló, pl. pincér, barman, vendéglátóipari eladó) nem követelheti a vendégtől, mert a foglalkoztatóval van munkavégzésre irányuló jogviszonyban (munkaviszonyban). A foglalkoztató (munkáltató, üzemeltető) pedig - a munkajogi szabályokból is

${ }^{48}$ Ld. Tervezet. Előterjesztés 3. Érdemes megemlíteni, a felszolgálási díj úgy van jelen a szabályozásban, hogy a vendéglátó üzlet felszolgálójaként a fogyasztótól közvetlenül kapott borravaló adómentes (ld. Szja tv. 1. számú melléklet 4.21. alpont).

${ }^{49} \mathrm{Ld}$. Tervezet. Melléklet 7. A Tervezet e tekintetben egyetlenegy forrást sem tartalmaz; az Előterjesztés 2. oldalán is csak ez áll: „A nemzetközi gyakorlatban általánosan elfogadott, hogy a vendéglátó üzletekben a fogyasztás ellenértékének százalékában meghatározott mértékű ún. szervízdíjat (felszolgálási díjat) is felszámítanak, ez azonban nem jogszabályban előírt kötelező jelleggel történik.” - az „általánosan elfogadott”-ra sem említ hivatkozást. Megjegyzendő, a felszolgálási díj nem szünteti meg a borravalót, mert a fogyasztó a felszolgálási díj mellett is adhat borravalót, s így nincs arról szó, hogy „a borravaló helyett felszolgálási díjat alkalmaznak”, hanem csak arról, hogy a fogyasztók a felszolgálási dij mellett kevésbé adnak borravalót. Továbbá, miként az alábbiakban ismertetésre kerülő pénzügyi jogi szabályozás alapján látható, még sem arról van szó, hogy a borravaló „nyomon követhető legyen”, a személyi jövedelemadó megfizetésével járjon, ne „zsebből zsebbe vándoroljon”, hanem igen jelentős „kedvezményről” (foglalkoztatotti, foglalkoztatói adó- és járulékmentességről).

${ }^{50}$ Ld. Indokolás, „Az 1. \-hoz”.

${ }^{51}$ Ld. Bíró György - Lenkovics Barnabás: Magyar polgári jog (I.). Általános tanok. Miskolc, Novotni, 1998. 3. kiad., 62., 79-80. Az említett polgári jogi alapelvekhez ld. pl. uo. 63-66., 75-81. és 82-90.

52 A felszolgálási díj bevezetésének megítélésénél a borravalóval, annak gyakorlatával való idézett összefüggéseket sem szabad figyelmen kívül hagyni (ld. pl. Indokolás, Harmadik rész: „A vendéglátásban elfogadott gyakorlat a borravaló, ugyanakkor az Európai Unió számos országában a borravaló helyett felszolgálási díjat alkalmaznak, amelynek adótartalma jobban nyomon követhető.”); ́́gy annak is jelentősége van, hogy a fogyasztók (vendégek) általában miért, kiknek szoktak borravalót adni (ez véleményünk szerint a tekintetben is releváns, hogy a jogalkotó hol húzza meg a „közreműködők” körének határát; nem szabad az üzemeltető „önkényes” döntésének teret engedni, sem az alanyi kör kiterjesztése - a vendégek a borravalót általában nem a „raktárosnak” szánják, sem a munkabér alacsony szinten tartása vonatkozásában, ami egyébként - a tisztesség, a rendeltetésszerű joggyakorlás és a joggal való visszaélés tilalmának elve, követelménye mellett - az alábbiakban tárgyalásra kerülő diszkriminációs problémák szempontjából is releváns). 
Debreceni Jogi Múhely 2017. (XIV.) 1-2.

Debreceni Egyetem, Állam- és Jogtudományi Kar, Debrecen

(University of Debrecen, Faculty of Law, Debrecen)

DOI 10.24169/DJM/2017/1-2/3

következően - nem háríthatja közvetlenül a vendégre (fogyasztóra) a foglalkoztatott (munkavállaló) munkájáért járó díjazás - akár csak részbeni - megfizetését. A „felszolgálási díj” léte, s mértéke tehát elvileg (fogalmilag) - a vendég szabad akaratától függ, kellene, hogy függjön. A vendéglátó üzlet üzemeltetője köteles (lenne) tiszteletben tartani a vendég ezzel kapcsolatos szabadságát (akarati, döntési és cselekvési autonómiáját). Ha az ún. „felszolgálási dij”” szerinti rész a foglalkoztatott jussa, akkor az - elvileg - a munkáltató által fizetendő munkabér körébe tartozik, kellene, hogy tartozzon; ha pedig nem, akkor az a vendég döntésétôl függ, kellene, hogy függjön.

A jóhiszeműség és tisztesség (jóerkölcs) polgári jogi alapelve (követelménye) belső feltétele és egyúttal tartalmi, terjedelmi korlátja minden alanyi jogosultságnak. Az alanyi jog látszatába burkolódzó, de a jóhiszeműség és tisztesség elvét sértő magatartás minimum jogalap nélkülinek, jogosulatlan magatartásnak minősül, azaz igényt nem keletkeztet, jogi védelmet nem kaphat, a célzott joghatást nem érheti el. Súlyosabb eseteiben pedig kifejezetten jogellenesnek minősíthető, vagy a törvény, vagy a bíró által, és a jogellenes magatartáshoz füződő szankciókkal sújtható. ${ }^{53}$

\subsection{A felszolgálási díj jelenleg hatályos pénzügyi jogi szabályozása}

$A_{z}$ S צ̌ja tv. 81. \-ának (5) bekezdése tartalmazza: felhatalmazást kap a vendéglátásért felelős miniszter, hogy rendeletben meghatározza a felszolgálási díj alkalmazásának, kifizetésének és felhasználásának részletes szabályait. Az Szja tv. 1. számú mellékletének 4.21. alpontja alapján a magánszẹéély által külön jogszabály szerint felszolgálási dij címen megszerzett bevétel, valamint a vendéglátó ü̃let felszolgálójaként a fogyasztótól közvetlenül kapott borravaló adómentes. ${ }^{54}$

A Htv. 40/C. $\$$ (3) bekezdésének b) pontja értelmében az (1) bekezdés szerinti bevételt csökkeenteni kell a felszolgálási dijjal. 55

A Tbj. 4. $\ \mathrm{k}$ ) pontjának 1. alpontja alapján a Tbj. alkalmazásában a felszolgálási díj és a vendéglátó ü̃let felszolgálójaként a fogyasztótól közvetlenül kapott borravaló is járulékalapot képerón jövedelem. A Tbj. 24. \$(1) bekezdésének a) pontja értelmében a foglalkoztatott nem fizet nyugdíjjárulékot, valamint egésaségbiztositási-és munkaeró-piaci járulékot a felszolgálási dij és a borravaló után. A Tbj. 26. \-ának (7) bekezdése alapján a külön jogszabály szerinti felszolgálási dij után a foglalko:tató - a foglalkoztatott helyett - 15\%-os mértékü nyugdijjárulékeot fizet, a vendéglátó ų̈̈let felszolgálója a fogyasztótól közvetlenül kapott borravaló után 15\% nyngdíjárulékot firethet, a vendéglátó üzlet felszolgálója a borravaló után fizethetô járulékot a személyi jövedelemadóról benyújtott bevallásában vallja be, a bevallás benyújtására előírt határidőig fizeti meg, továbbá a bevallásában adatot szolgáltat a 15\% nyugdíjjárulék alapjáról és összegéről.

A Tny. 22. S (1) bekezdésének e) pontja értelmében az öregségi nyngdíj alapját képezón havi átlagkereset összegét az 1988. január 1-jétől a nyugdíj megállapításának kezdő napjáig elért (kifizetett), a kifizetés idején érvényes szabályok szerint nyugdíjjárulék alapjául szolgáló kereset, jövedelem havi átlaga alapján kell meghatározni, és keresetként, jövedelemként a felszolgálási dij 81\%-át is figyelembe kell venni. A Korm. r. 14. S-ának (5) bekezdése is tartalmazza, hogy a felszolgálási dij, illetöleg a fogyasztótól közvetlenül kapott borravaló 81 százalékáat kell a havi átlagkereset meghatározásánál keresetként, jövedelemként figyelembe venni.

Az Art. 31. 』 (2) bekezdésének 28. pontja szerint: „A munkáltató, a kifizető (ideértve az egyéni

${ }^{53}$ Ld. Biró- Lenkovics i. m. 80., és 82-90.

${ }^{54}$ Ld. még Indokolás, „Az 1. \-hoz” (vö. uo., „A 4. \-hoz”).

${ }_{55}$ A Htv. 52. \22. pontjának a) alpontja alapján a Htv. alkalmazásában nettó árbevétel: a számviteli törvényben meghatározott értékesités nettó árbevétele (egyszeres könyvvitelt vezető vállalkozó esetében: a pénzügyileg rendezett nettó árbevétel és a nem pénzben kiegyenlített értékesítés nettó árbevételének együttes összege), csökkentve a társasági adóról és az osztalékadóról szóló törvény szerinti jogdijból származó, árbevételként elszámolt ellenértékkel, a jövedéki adó fizetésére kötelezett vállalkozó esetében az adóhatósággal elszámolt - az egyéb szolgáltatások értékeként, illetve az egyéb ráfordítások között kimutatott - jövedéki adó összegével, továbbá az egyéb ráfordítások között kimutatott, az adóhatósággal elszámolt regisztrációs adó, energiaadó, népegészségügyi termékadóról szóló törvény szerinti alkoholos ital utáni népegészségügyi termékadó összegével, feltéve, ha az így elszámolt regisztrációs adó, energiaadó, népegészségügyi termékadó összege az értékesítés nettó árbevételét növelte, valamint a külön jogszabály szerinti felszolgálási dij árbevételként elszámolt összegével, a b)-h) alpontokban foglalt eltérésekkel. Ld. még Indokolás, Második rész. 
Debreceni Jogi Múhely 2017. (XIV.) 1-2.

Debreceni Egyetem, Állam- és Jogtudományi Kar, Debrecen

(University of Debrecen, Faculty of Law, Debrecen)

DOI 10.24169/DJM/2017/1-2/3

vállalkozónak nem minősülő magánszemély munkáltatót is), illetôleg az 52. \(4) bekezdésének 1), p), r), s), t) és v) pontjaiban meghatározottak a rájuk vonatkozó bevallási gyakoriságtól függetlenül, havonként, a tárgyhót követő hónap 12. napjáig elektronikus úton bevallást tesznek az adó- és/vagy társadalombiztosítási kötelezettségeket eredményező, magánszemélyeknek teljesített kifizetésekkel, juttatásokkal összefüggő valamennyi adóról - kivéve a kamatjövedelem adóról -, járulékokról és/vagy az alábbi adatokról: [...] 28. a felszolgálási dij után fizetett nyugdijjárulék alapjáról és összegéröp’ ${ }^{56}$

\subsection{A felszolgálási díj alkotmányossági problémái}

\subsubsection{A fogyasztók megfelelo" tájéko ztatáshoz való jogának sérelme}

A vendéglátásért felelős miniszter törvényben felhatalmazást kapott, hogy a felszolgálási díj alkalmazásának és felhasználásának szabályait jogszabályban megállapítsa, ${ }^{57}$ a rendeleti reguláció azonban mivel a felszolgálási díj eredetileg (az R.-ben) mértékben jelent meg, s a gyakorlatban jelenleg is így érvényesül - véleményünk szerint ellentétes az Fgytv. azon rendelkezésével, amely kimondja, hogy: „,[a]z eladási árat és az egységárat, illetve - határon átnyúló szolgáltatásnyújtás kivételével - a szolgáltatás díát Magyarország törvényes fizetőeszközében kifejezve, a fizetőeszköz nemét (forint) vagy annak rövidítését (Ft) megjelölve kell feltüntetni." ${ }^{58}$ A felszolgálási díj ebből a szempontból - túl azon alkotmányos követelményen, hogy az alacsonyabb szintü jogszabály nem lehet ellentétes a magasabb sżintü jogszabállyab9 - sérti a fogyasztók jogos érdekét, megfelelő tájékoztatáshoz való jogát, ${ }^{60}$ mert nyilvánvalóan nem lehet ugyanannyi idő alatt megmondani például a 3.760.- Ft 8\%-át, mint elolvasni azt, hogy (kerekítve) 301.- Ft.

\subsubsection{Diškriminációs problémák.}

A Tbj. 19. \-ának (2)-(3) bekezdései a következő - jelenleg hatályos - szabályokat tartalmazzák: „(2) A biztosított, a kiegészítő tevékenységet folytató egyéni és társas vállalkozó, valamint tagi munkavégzés esetén a szociális szövetkezeti tag által fizetendő nyugdíjjárulék mértéke 10 százalék. (3) A biztosított által fizetendő egészségbiztosítási- és munkaerő-piaci járulék mértéke 8,5 százalék. Az egészségbiztosítási- és munkaerő-piaci járulékon belül a természetbeni egészségbiztosítási járulék 4 százalék, a pénzbeli egészségbiztosítási járulék 3 százalék, a munkaerő-piaci járulék 1,5 százalék."

Az ismertetett szabályozás szerint a felszolgálási díj ugyan általános forgalmi adót tartalmaz, ami jelenleg 27\% $\%^{61}$ (mint a szociális hozzájárulási adón ${ }^{62}$ ), és így, ennyiben a központi költségvetési bevétel úgymond „biztosított”, ${ }^{63}$ de miután azt a fogyasztó fizeti meg, a munkabérrel kapcsolatos adó- és járulékfizetési

\footnotetext{
${ }^{56}$ Ld. még NGM r. 8-9. melléklet.

57 Ld. egyes pénzügyi tárgyú törvények módosításáról szóló 2005. évi LXXXII. törvény 10-11. 『; és Indokolás, Harmadik rész.

${ }^{58}$ Ld. Fgytv. 14. \(4) bekezdés. Vö. uo. (3) és (5) bekezdés: „,(3) Az eladási árat, az egységárat, illetve a szolgáltatás diját egyértelműen, könnyen azonosíthatóan és tisztán olvashatóan kell feltüntetni.” „(5) A termék eladási áraként és egységáraként, illetve a szolgáltatás díjaként a fogyasztó által ténylegesen fizetendő, az általános forgalmi adót és egyéb kötelező terheket is tartalmazó árat kell feltüntetni.”

59 Ld. Alaptörvény 15. cikk (4) bekezdés: „A Kormány rendelete törvénnyel nem lehet ellentétes.”, 18. cikk (3) bekezdés: „A Kormány tagja törvényben vagy kormányrendeletben kapott felhatalmazás alapján, feladatkörében eljárva, önállóan vagy más miniszter egyetértésével rendeletet alkot, amely törvénnyel, kormányrendelettel és a Magyar Nemzeti Bank elnökének rendeletével nem lehet ellentétes.”

${ }^{60}$ Vö. pl. Alaptörvény M) cikk (2) bekezdés: „Magyarország biztosítja a tisztességes gazdasági verseny feltételeit. Magyarország fellép az erőfölénnyel való visszaéléssel szemben, és védi a fogyasztók jogait.”

${ }^{61}$ Ld. az általános forgalmi adóról szóló 2007. évi CXXVII. törvény 82. \(1) bekezdés: „(1) Az adó mértéke az adó alapjának 27 százaléka."

${ }^{62}$ Ld. egyes adótörvények és azzal összefüggő egyéb törvények módosításáról szóló 2011. évi CLVI. törvény 459. S (1) bekezdés első mondat: „A számított adó az adóalap 27 százaléka.”

63 Ilyen szempontból a felszolgálási díj „kiváltja” a borravalót; de miután a vendéglátó üzlet felszolgálójaként a fogyasztótól közvetlenül kapott borravaló adómentes, és még mindig a borravaló (nem a felszolgálási díj) az elterjedtebb (jelentősen), a felszolgálási díj a központi költségvetés nézőpontjából sem tudta igazán felváltani a borravalót.
} 
Debreceni Jogi Múhely 2017. (XIV.) 1-2.

Debreceni Egyetem, Állam- és Jogtudományi Kar, Debrecen

(University of Debrecen, Faculty of Law, Debrecen)

DOI 10.24169/DJM/2017/1-2/3

kötelezettségekhez képest (ami a munkavállaló oldalán: 15\% szja, ${ }^{64}$ 10\% nyugdijjárulék, 8,5\% egészségbiztosítási és munkaerô-piaci járulék) - noha voltaképpen a munka díjazásáról van szó - a munkavállaló és a munkáltató szempontjából jóval kedvezőbb, mert a foglalkoztatottnak nyugdíjjárulék-, valamint egészségbiztosítási és munkaerő-piaci járulékfizetési kötelezettsége nem keletkezik, továbbá adómentes (a foglalkoztatónak a 15\%-os mértékủ nyugdíjjárulékot a felszolgálási dijból kell fizetnie).

Ez a „megoldás” véleményünk szerint - túl azon, hogy a munka (felszolgálás, kiszolgálás) díjazásának (pénzben kifejezett ellenértékének), mint költségnek a jelen esetben is a bérköltségek között kellene szerepelnie - a diszkrimináció-tilalom alkotmányos követelménye ${ }^{65}$ szempontiából is aggályos. A felszolgálási díj ugyanis - a fogyasztó nézôpontjából fennálló - kötelező volta ${ }^{66}$ folytán teljesítménybérrészként funkcionálva, foglalkoztatotti, foglalkoztatói adó- és járulékmentesség mellett diszkriminatív módon van jelen a szabályozásban: más, szintén teljesítmény- vagy vegyes (időbért és teljesítménybért összekapcsoló) bérezési formában foglalkoztatott, a szabályozás szempontjából az érintettekkel egy csoportba tartozó, homogén - összehasonlítható, azonos helyzetben levő - jogalanyi kört képező, borravalós munkakörben foglalkoztatott munkavállalók ${ }^{67}$ és munkáltatóik részére nincs biztosítva ez az igen jelentős „kedvezmény” (mentességi lehetőség). ${ }^{68}$

További diszkriminációs probléma, hogy a szabályozás szerint a vendéglátó üzlet felszolgálójaként a fogyasztótól közvetlenül kapott borravaló adómentes, ${ }^{69}$ akkor is, hogy ha az adott üzletben nem számítanak fel felszolgálási dijat, más foglalkozások ${ }^{70}$ esetén a borravaló adóköteles. ${ }^{71}$

Véleményünk szerint ennek a (személyek közötti, munka honorálásával kapcsolatos közteherviselési) megkülönböztetésnek - végső soron az emberi méltóság általános személyiségi jogával, ${ }^{72}$ de „az egyenlő munkáért mindenkinek, bármilyen megkülönböztetés nélkül, egyenlő bérhez van joga"ᄁ3 és a közteherviselés, ${ }^{74}$ illetőleg a jogállamiság alkotmányos követelményével ${ }^{75}$ is összefüggésben - objektíve

\footnotetext{
${ }^{64}$ Ld. Szja tv. 8. \(1) bekezdés: „(1) Az e törvény hatálya alá tartozó jövedelem után az adó mértéke - ha e törvény másként nem rendelkezik - az adóalap 15 százaléka."

${ }^{65}$ Ld. Alaptörvény XV. cikk (1)-(2) bekezdés: „(1) A törvény előtt mindenki egyenlő. Minden ember jogképes. (2) Magyarország az alapvető jogokat mindenkinek bármely megkülönböztetés, nevezetesen faj, szín, nem, fogyatékosság, nyelv, vallás, politikai vagy más vélemény, nemzeti vagy társadalmi származás, vagyoni, születési vagy egyéb helyzet szerinti különbségtétel nélkül biztosítja."

${ }^{66}$ A Tervezet megfogalmazásában: „A szervízdij esetében a vendégnek nincs választási lehetősége, az nem önkéntes. A borravaló, ami az eltitkolt jövedelem döntő részét teszi ki, viszont önkéntes, alapvetően a nyújtott szolgáltatás színvonalától függ." (Előterjesztés 2.).

${ }^{67}$ Ld. pl. az üzemanyagtöltő-állomások - miként a vendéglátó üzletek is - működnek önkiszolgáló és kiszolgáló rendszerben is, a borravaló is jelen van, a kiszolgálás esetén a munkabérből (annak költségéből) a szabályozás szerint nem szabad kiszervezni „kiszolgálási díjat”; vö. még pl. szállodai portás, recepciós, fodrász, taxis. Mindemellett megemlítendő, hogy a „közremúködők” - miként azt kimutattuk - tágabb kört fog át, mint a borravalós munkakörben foglalkoztatott munkavállalók köre (ld. pl. raktáros - vö. „üzlet” fogalma; s így a „felszolgálási díj” elnevezés - a fogyasztók számára is - nagyon megtévesztő).

68 2005-ben az ellenzéki felszólalásra adott válaszként - emlékezetünk szerint - az hangzott el, hogy a szabályozást majd kiterjesztik más területekre is (az abszurditás azonban e tekintetben nem fokozódott).

${ }^{69}$ Ld. Szja tv. 1. számú melléklet 4.21. alpont.

${ }^{70}$ Ld. pl. szállodai portás, recepciós, fodrász, taxis, benzinkutas.

${ }^{71}$ Ld. Szja tv.

${ }^{72}$ Ld. Alaptörvény I. cikk: „(1) AZ EMBER sérthetetlen és elidegeníthetetlen alapvető jogait tiszteletben kell tartani. Védelmük az állam elsőrendű kötelezettsége. (2) Magyarország elismeri az ember alapvető egyéni és közösségi jogait. (3) Az alapvető jogokra és kötelezettségekre vonatkozó szabályokat törvény állapítja meg. Alapvető jog más alapvető jog érvényesülése vagy valamely alkotmányos érték védelme érdekében, a feltétlenül szükséges mértékben, az elérni kívánt céllal arányosan, az alapvető jog lényeges tartalmának tiszteletben tartásával korlátozható. (4) A törvény alapján létrehozott jogalanyok számára is biztosítottak azok az alapvető jogok, valamint őket is terhelik azok a kötelezettségek, amelyek természetüknél fogva nem csak az emberre vonatkoznak.”, II. cikk: „Az emberi méltóság sérthetetlen. Minden embernek joga van az élethez és az emberi méltósághoz, a magzat életét a fogantatástól kezdve védelem illeti meg."

${ }^{73}$ Ld. Alaptörvény XII. cikk (1)-(2) bekezdés, XV. cikk (1)-(2) bekezdés.

${ }^{74} \mathrm{Ld}$. Alaptörvény XXX. cikk (1)-(2) bekezdés.

${ }^{75}$ Ld. Alaptörvény B) cikk (1) bekezdés.
} 
Debreceni Jogi Múhely 2017. (XIV.) 1-2.

Debreceni Egyetem, Állam- és Jogtudományi Kar, Debrecen

(University of Debrecen, Faculty of Law, Debrecen)

DOI 10.24169/DJM/2017/1-2/3

(tárgyilagos mérlegelés szerinti) ésszerű (alkotmányos) indoka nincsen, így önkényes disælkriminációnak minősül.

Az R. betúi szerint az is elóállhat, hogy az üzemeltető (munkáltató) a munkabért a minimálbér szintjén tartja, illetve a munkavállalókkal arra leszállítja, és a felszolgálási díjat alkalmazza, azt növelve és növelve, akár kétszáz-százalékosra, a bruttó dijat úgy csökkentve, hogy a vendégnek ne kelljen többet fizetnie, mint az eredeti bruttó díj 15\%-os felszolgálási díjjal növelt összege, miközben az állam más munkáltatóknak és munkavállalóknak nem biztosítja ezt a kedvezményes (mentességi) „lehetőséget”.

\subsubsection{A 15\%-os felsö határ eltörlésének kérdése az. Irányelv tükrében}

A felszolgálási díj 15\%-os felső határa hatályon kívül helyezésének megítélése tekintetében - véleményünk szerint - meghatározó jelentősége van annak, hogy a felszolgáló közremúködésével történó kiszolgálás az ü̃letben, dijazás ellenében nyújtott komplex (sajátos) vendéglátó szolgáltatás szerves részét képezi (lényegi sajátja), ${ }^{76}$ amely miatt a munka kötelező dijjazásának a vendéglátó szolgáltatás díján belül, munkabérként kell(ene) megjelennie. A szállítási, kiszállási díj esetében a szolgáltatás nyújtása nem üzletben történik.

Az Irányelv a Közösség valamely tagállamában letelepedett szolgáltatók által nyújtott szolgáltatásokra alkalmazandó. ${ }^{77}$ Az Irányelv alkalmazásában „,szolgáltatás”: „a Szerződés 50. cikkében említett, rendszerint dijazás ellenében nyújtott bármely önálló gazdasági tevékenység”. ${ }^{78} \mathrm{Az}$ Irányelv rendelkezéseit tekintve, a „kérdés” szempontjából - véleményünk szerint - a 15. cikk (2) bekezdés g) pontjának értelmezése vetődik fel: „A tagállamok megvizsgálják, hogy jogrendszerük a szolgáltatási tevékenység nyújtására való jogosultságot vagy a szolgáltatási tevékenység gyakorlását az alábbi megkülönböztetésmentes követelmények bármelyikének való megfeleléshez köti-e: $[\ldots]$ g) rögzített legalacsonyabb és/vagy legmagasabb dijtételek, amelyeknek a szolgáltatóknak meg kell felelnie”.

Véleményünk szerint az Irányelvnek sem az idézett, sem más rendelkezéseiből nem következik a 15\%-os felső határ eltörlésének kötelezettsége, mert az Irányelv szerinti „szolgáltatás” a vendéglátó szolgáltatás (nem a „kiszolgálás”), amelynek része a szóban forgó kiszolgálás; a vendéglátó szolgáltatásnak van díja, amely a mai magyar állami szabályozás szerint nem rögzített; a kiszolgálás viszont önállóan fizikailag sem létezik, az a vendéglátó szolgáltatás szerves része (pusztán a „kiszolgálásért” díjat nem lehet kérni, csak a vendéglátó szolgáltatásért). Igy, véleményünk szerint nincs szükség az Irányelv 15. cikk (3) bekezdés b)-c) pontja szerinti szükségességi-arányossági feltételek ellenőrzésére sem. Az Irányelv 4. cikkének 8. pontja alapján „közérdeken alapuló kényszerítő indok” (szükségességi feltétel) például a fogyasztók védelme. Az arányosság tekintetében: a felszolgálási díj bevezetésének Tervezet és Indokolás szerinti (idézett) célja - a központi költségvetés szempontjából - a borravaló „kiváltása”; a 15\%-os felső határ célja nyilvánvalóan a fogyasztók védelme (az intézményhez képest a józan ész megtartása); a 15\%-os felső határ bőven eléri a borravaló szokásos mértékét, amely mellett a fogyasztók még adhatnak borravalót is; a mérték meghatározásánál nyilvánvalóan nem hagyható figyelmen kívül a felszolgálási díj rendeltetése, célja, funkciója (a borravaló szokásos mértékével való összefüggése, a vendégek borravalóval kapcsolatos szándéka és a munkabér jelentősége), s így akár az arányosság is megállna.

Véleményünk szerint a tagállamoknak nincsen olyan kötelezettségük, hogy a felszolgálási díjat be kellene vezetniük, ${ }^{79}$ illetve jogrendszerükben kellene tartaniuk; ha pedig azt ennek ellenére mégis megteszik, ehhez

\footnotetext{
${ }^{76}$ A „kiszolgálás” nem önálló gazdasági tevékenység (a „semmiben” nem tud létezni).

${ }^{77}$ Ld. Irányelv 2. cikk (1) bekezdés. Ennek kapcsán is hangsúlyozandó, hogy a szóban forgó „kiszolgálás” nem önálló szolgáltatás, nem önálló gazdasági tevékenység, üzletben történik, nem tud létezni a vendéglátó szolgáltatás nélkül (annak szerves része, lényegi sajátja); a szállítás és a kiszállás nem üzletben történik.

${ }_{78}^{7 d}$ d. Irányelv 4. cikk 1. pont.

${ }^{79}$ A Tervezetnek „A” és „B” változata volt: „Az »A« változat, a szolgáltatás színvonalától, az éttermi áraktól, a piaci körülményektől és lehetőségektől függetlenül is felszolgálói dijat kell fizetni, amelyet a fogyasztók egyértelmúen áremelésként élnek meg. Kedvezőtlen idegenforgalmi hatása is van, mert azoknak az üzleteknek, amelyek éves program alapján előre értékesítik szolgáltatásaikat, azokat éppen az idegenforgalmi szezon kezdetén módosítaniuk kell, mely hatással lehet későbbi üzleti kapcsolataikra is. A kötelezô díj, beavatkozás a piaci folyamatokba is. Mindezekről az Ágazati Párbeszéd Bizottság egyes tagjaival, a szakmai képviseletekkel is egyeztetést folytattunk, akik
} 
Debreceni Jogi Múhely 2017. (XIV.) 1-2.

Debreceni Egyetem, Állam- és Jogtudományi Kar, Debrecen

(University of Debrecen, Faculty of Law, Debrecen)

DOI 10.24169/DJM/2017/1-2/3

képest a józan ész, (a „mérték”) őket is köti. S ha ez nem így lenne, ne csodálkozzunk, ha előbb-utóbb mindenféle „kiszolgálást” kiszerveznek (pl. a taxis a fuvardíj mellett „kiszolgálási” díjat követelhetne az utastól, mert beteszi az utas bőröndjét a taxiba, hogy az állam „kiváltsa” a taxis borravalóját).

\section{Konklúzió}

Véleményünk szerint, annak ellenére, hogy a jogalkotó megkülönbözteti a felszolgálási díjat a borravalótól, a felszolgálási díj a vendéglátás komplexitásától, sajátos szolgáltatási jellegétől, igaz vendégszeretetétől 180 igen távol esik (különösen, ha az azzal kapcsolatos tájékoztatás ${ }^{81}$ elmarad vagy hiányos). Ha a „felszolgálási díj” a munkavállaló jussa, akkor az a munkáltató által fizetendő munkabér körébe tartozik; ha pedig nem, akkor az a vendég döntésétől függ.

A teljesítménybér (a forgalom utáni díjazás), illetve egy részének bruttó díjon kívülre helyezésével, a díjazás egy részének a vendég számára történő számszerủ megjelenítésével a szolgáltatás tartalmából egyre inkább eltűnik, kikerül az emberi, ami nem ölt testet a felszolgálási dijban, hanem „semmivé”, a szolgáltatás „ürességévé” válik, mert az csak pénz, dolog, ami a fizikai rend részét képező létező pusztán. Az ember, így a vendég is azonban ennél jóval többre vágyik, az igazi, emberi, azaz szeretetteljes, önzetlen magatartásra (még akkor is, ha a munkavállaló természetesen díjazásban részesül82), melyet a felszolgálási dij csak beárnyékol, kiüresít, a visszterhességet hangsúlyozza mind a vendég, mind a munkavállaló számára, s ez károsan visszahat a társadalomra is (az emberek egyre inkább a puszta érdek, haszon rabságában élnek), már a vendéglátós is egyre kevésbé igaz vendéglátós, aki önmagáert szereti a másik embert, ${ }^{83}$ a vendéget, hanem mindinkább a pénzéért szereti, sőt elóbb-utóbb már nem is őt, hanem a pénzét, csak a pénzét szereti, - és a csúszós lejtőn, ki tudja, hol áll meg - a ,jogalkotó” is.

Véleményünk szerint - a kifejtett okok miatt - a felszolgálási díj szabályozása ${ }^{84}$ és a borravaló szóban forgó adómentessége sérti az Alaptörvény XV. cikkének (2) bekezdésében megfogalmazott megkülönböztetési tilalmat, ${ }^{85}$ ezért alaptörvény-ellenes, ${ }^{86}$ a jogalkotó által hatályon kívül helyezendő, illetve az Alkotmánybíróság által megsemmisítendő; az említett értelmezési és tájékoztatási problémák pedig az Alaptörvény B) cikkének (1) bekezdése és M) cikkének (2) bekezdése, valamint 18. cikkének (3) bekezdése

éppen az előzőekben leírtak miatt nem támogatnák a felszolgálói díj kötelező bevezetését. A »B« változat a felszolgálói díjat nem tenné kötelezővé, csak megteremtené a lehetőséget arra, hogy az európai gyakorlathoz hasonlóan az üzemeltető felszolgálási díjat állapíthasson meg maximum $10 \%$ mértékben. A »B « változat nem avatkozik be a piaci folyamatokba, az üzemeltetô maga dönti el, hogy felszámol-e ilyen díjat vagy sem.” (Előterjesztés 2-3.) - végül is az R.-rel a „B” változat került elfogadásra, 15\%-os felső határral (megjegyzem, a „felszolgálói díj” a „felszolgálási díj” elnevezésnél is megtévesztőbb lett volna - vö. „közreműködők”).

${ }^{80}$ Ld. Hámori (2003) i.m. 14-18. (vö. uo. 19-21.).

${ }^{81}$ Ld. R2. 6. \ (2) bekezdés, Fgytv. 14. $\int(3)-(4)$ bekezdés.

82 Hisz’ jár a munkásnak a bére (ld. pl. Lev 19,13; vö. pl. MTörv 24,14-15; Tób 4,14; Lk 10,7; Jak 5,4).

${ }^{83}$ Ld. Hámori Antal: A vendéglátás etikája. Budapest, Bodnár Bt., 2010. 86.

${ }^{84}$ Ld. R., R2. 6. \ (2) bekezdés „felszolgálási,” szövegrész, Szja tv. 81. \(5) bekezdés, 1. számú melléklet 4.21. alpont, Htv. 40/C. \(3) bekezdés b) pont, 55. \$22. pont a) alpont vonatkozó szövegrész, Tbj. 4. \ k) pont 1. alpont, 24. \(1) bekezdés a) pont, 26. \(7) bekezdés, Tny. 22. \(1) bekezdés e) pont, Korm. r. 14. \ (5) bekezdés, Art. 31. \(2) bekezdés 28. pont, NGM r. 8-9. melléklet vonatkozó részek.

85 „A megkülönböztetés tilalma arra vonatkozik, hogy a jognak mindenkit egyenlőként (egyenlő méltóságú személyként) kell kezelnie, azaz az emberi méltóság alapjogán nem eshet csorba, azonos tisztelettel és körültekintéssel, az egyéni szempontok azonos mértékủ figyelembevételével kell a jogosultságok és kedvezmények elosztásának szempontjait meghatározni." [pl. 9/1990. (IV. 25.) AB határozat, Indokolás IV.; 21/1990. (X. 4.) AB határozat, Indokolás III.]

${ }^{86}$ Vö. pl. 9/1990. (IV. 25.) AB határozat, Indokolás IV.; 21/1990. (X. 4.) AB határozat, Indokolás III., V., XI. („,...az Alkotmány 70/A. đ-ában foglalt jogegyenlőség... elv nemcsak a természetes, hanem a jogi személyekre is vonatkozik.”); 7/1991. (II. 28.) AB határozat, Indokolás IV. 5. (vö. uo. 4.); 34/1992. (VI. 1.) AB határozat, Indokolás III. 4-5.; 54/1992. (X. 29.) AB határozat, Indokolás III.; 61/1992. (XI. 20.) AB határozat; 881/B/1991. AB határozat, Indokolás III.; 54/1993. (X. 13.) AB határozat, Indokolás II. 2-3.; 35/1994. (VI. 24.) AB határozat 1., Indokolás III. 2., 5., és Dr. Sólyom László alkotmánybíró párhuzamos indokolása; 59/1995. (X. 6.) AB határozat, Indokolás II. 3.3.; 68/1997. (XII. 29.) AB határozat, Indokolás III.; 27/1999. (IX. 15.) AB határozat, Indokolás IV. 2 . 
Debreceni Jogi Múhely 2017. (XIV.) 1-2.

Debreceni Egyetem, Állam- és Jogtudományi Kar, Debrecen

(University of Debrecen, Faculty of Law, Debrecen)

DOI 10.24169/DJM/2017/1-2/3

alapján is aggályosak, s ekként ugyancsak orvoslásra szorulnak. ${ }^{87}$

\section{C) Végkövetkeztetések}

1. Az alapvetố jogok biz̨tosa az Alaptörvény B) cikkének (1) bekezdése, M) cikkének (2) bekezdése és 18. cikkének (3) bekezdése, a fogyas ztók megfeleló tájéko żtatáshoz való joga, a jogállamiság (jogbiztonság) és a ,jogforrási bierarchia" tisz̨teletben tartásának alkotmányos követelménye szempontjából panaszos által megfogalmazott „értelmezési és tájékoztatási problémákekal" nem foglalkozott, e tekintetben adós maradt; a panasszal érintett problémakört nem tekintette át alaposan, azt nagyrészt át sem tekintette, az Alaptörvény XV. cikkének (2) bekezdésén túl a Nemzetgazdasági Minisztérium rendkivül „szikeáa” tájékoztatási szintjén rekedt, ami elfogadhatatlan.

2. A panasz a borravaló adózásának „kettéágazásáról’ is szól; a beadvány részét képező alkotmánybírósági indítványtervezet - pontos jogszabályhely-megjelölésekkel - a nemzetgazdasági minisztériumi tájékoztatás vonatkozó részeit is tartalmazza.

3. A beadványból látható, hogy a panaszos nem téveszti össze a borravalót a felszolgálási díjjal; a „betúket” a megfogalmazott, de meg nem válaszolt „értelmezési és tájékoztatási problémák”, a panasz megfelelő, teljeskörű megválaszolására kellett volna fordítani; a fentiek alapján elmondható, hogy az alapvető jogok biztosa számos beadványrésszel nem foglalkozott, ami pótlandó.

4. Helytelen, hogy a „tájékoztatás”, a válasz a „szervízdíjat”, a „sžervízdíj” szót is tartalmazza; a Nemzetgazdasági Minisztériumnak és az alapvető jogok biztosának is - miként a vendéglátó üzletek üzemeltetőinek is - a ,felszolgálási dî̉” megnevezést kell használniuk; a dezinformációt, a „zavaros”, megtévesztő, nem egyértelmú, nem világos - gyakorlatban elterjedt - megnevezés(eke)t meg kell szüntetni.

5. Ugyanígy „túlzásnak” tartom a borravaló vonatkozásában „szokásjogi alap”-ról beszélni; legfeljebb szokásról lehet szó.

6. Az R. tervezete vonatkozásában is utaltam rá, elfogadhatatlan, hogy a jogalkotó, vagy akár a jogalkalmazó „a vonatkozó európai gyakorlat átvételé”-ről szóljon úgy, hogy nem jelöl meg konkrét jogszabályhelyeket. Magyarországon is, 2005. október 1. elôtt is alkalmaztak „felszolgálási dîj”-at, „szervízdíł”-at, „,couvert”dijat, „teríték”-dijat: jogellenesen! 88 A „nagy Nyugaton” is tapasztalhattunk jogsértést: például a vendéglátó üzletben nem adtak számlát, nyugtát.

7. A „turisztikai, vendéglátást ösztönzó gazdaságpolitikai céloknak való megeleléé" (és az általam ugyancsak említett, idézett egyéb szándék) pedig szintén nem „mindenható”, nem határtalan! A jogalkotónak és a jogalkalmazónak, így az alapvetó jogok biztosának is, bele kell mennie azokba a ,jogértelmezési és egyéb problémák."-ba, a jogbiztonság alkotmányos követelménye, a fogyasztók védelme szempontjából is, amelyek a beadványban és a fentiekben, véleményem szerint részletesen kifejtve, kellóen megindokolva előtte hevertek, s fekszenek.

8. Az egyenló bánásmód követelményének a kérdése tekintetében hangsúlyozom: ha a beadványban (annak lábjegyzeteiben is) foglaltak szerinti, jelentős közelségben megnézzük, megvizsgáljuk a problémákat, az indokolatlan különbségtétel és egyben az emberi méltóság sérelme nem vetődik el olyan „,prózaian”, mint az alapvető jogok biztosának válaszában; túl azon, hogy a megkülönböztetés a kifejtettek szerint nemcsak a „borravaló”, hanem a „felszolgálási dîj” vonatkozásában is fennáll, az ismertetett jogértelmezési problémák. tükrében, az „üzlę" valamennyi munkavállalójának jussa a felszolgálási dij (nemcsak a "felszolgáló” munkakörben foglalkoztatottaknak), nehezen indokolható meg, például, hogy míg a vendéglátó üzlet munkavállaló könyvelőjének, takarítójának „felszolgálási díjas” kedvezménye, mentessége van, és az említettek szerint a munkáltatónak is, addig a nem vendéglátó vállalkozások ugyanazon munkakörben foglalkoztatott munkavállalói és ezen utóbbiak munkáltatói mindettől elesnek, a „barman” munkakörben

${ }^{87}$ A beadvány részét képező alkotmánybírósági indítványtervezet utolsó mondata: „A fentiek alapján kérem a tisztelt Alkotmánybíróságot, hogy a kifejtettek szerint állapítsa meg az ezen indítvánnyal támadott rendelkezések alaptörvény-ellenességét és azokat semmisítse meg."

88 Hámori (2003) i. m. 18-21. 
Debreceni Jogi Múhely 2017. (XIV.) 1-2.

Debreceni Egyetem, Állam- és Jogtudományi Kar, Debrecen

(University of Debrecen, Faculty of Law, Debrecen)

DOI 10.24169/DJM/2017/1-2/3

foglalkoztatott munkavállaló ugyanabban a „szolgáltatási szelktor"-ban (szintén a „vendéglátás”-on beliil) van, mint a „felszolgáló”, sőt ugyanabban az „üzlet”-ben, az előbbi fogyasztótól közvetlenül kapott borravalója azonban nem adómentes, mert nem felszolgálóként kapta, hanem barmanként, miközben akár maga szolgálta fel a koktélt, de ugyanígy ,nehezen követhetô" a szállodai recepciós esete is; tehát nem csak a „vendéglátás és más szolgáltatási szektor” szerinti különbségtételről van szó, hanem a „vendéglátás”-on belüli megkülönböztetésről is. Ha valaki nem érzi legalább az ugyanabban a szolgáltatási szektorban foglalkoztatott, vendéget kiszolgáló munkavállalók emberi méltóságának sérelmes érintettségét, az lehet, hogy nem gondolt bele mélyebben a szóban forgó kedvezményben, mentességben nem részesülő emberek sértettségébe, hátrányos megkülönböztetésébe.

9. S végül, „hab a tortán”, avagy a „söralátéten”: a 16SZJA jelű bevallás 09-es lapjának I. része megtévesztöen „A vendéglátó üzlet felszolgálójaként a fogyasztótól közvetlenül kapott borravaló után a nyugdíjjárulék kötelezettsége” címet viseli, „A borravalót terhelő 15\%-os nyugdíjjárulék összegé”-ról szól (mintha azt fizetni kellene); e megtévesztést a „söralátét” (általam kinyomtatott formájában) háromszáznegyvennyolc oldalas Útmutatója „helyre teszi” ugyan, mert (a vonatkozó részében, a 176. oldalon) tartalmazza, hogy: „Ezeket a sorokat csak abban az esetben kell kitöltenie, ha Ön vendéglátó üzlet felszolgálójaként a fogyasztótól közvetlenül kapott borravaló után kíván 15\%-os nyugdíjjárulékot fizetni.” (a 280. sorhoz: „Ebbe a sorba a borravaló címén kapott teljes összeget írja be akkor, ha ezen összeg után 15\%-os mértékú nyugdíjárulékot kíván fizetni.”), azonban helyes lenne, ha a 09-es lap (az Útmutatóhoz képest a „fó dolog") is ezt tükrözné, ${ }^{89}$ mert ez van összhangban az idézett törvényi szabállyal, és noha van Útmutató, azért a „söralátét” se legyen megtévesztó".

Information about the regulation of service charges in relation to the procedure of the Commissioner for Fundamental Rights - Summary

The article introduces the statutory regulation of service charges in relation to the procedure of the Commissioner for Fundamental Rights in a complex manner, by referring to all affected parts of the statutory system providing a detailed and critical analysis, reasoning, furthermore the article also refers to the statutory dogmatic, constitutional issues, controversies, maladministration and interpreting questions related to service charges, by also making reference to the halts in consumer protection - repealing the $15 \%$ upper limit. The article presents the answer of the Commissioner for Fundamental Rights and the necessary reflection to this answer. The author publishes his thorough and firm opinion, which takes into consideration consumer protection and discrimination aspects, in a usable manner for legislators and law enforcement bodies, and summarises the final conclusions, ,missing items” complied in nine points.

89 Ld. pl.: „A vendéglátó üzlet felszolgálójaként a fogyasztótól közvetlenül kapott borravaló után fizethető nyugdíjjárulék” cím, „A borravaló után fizethető 15\%-os nyugdíjjárulék összegé”-ről szólva. 